\title{
Visualising Cholesterol in Brain by On-Tissue Derivatisation and Quantitative Mass Spectrometry Imaging
}

Roberto Angelini ${ }^{1}$, Eylan Yutuc ${ }^{1}$, Mark F Wyatt ${ }^{1}$, Jillian Newton ${ }^{2}$, Fowzi Adam Yusuf ${ }^{1}$, Lauren Griffiths ${ }^{1}$, Benjamin Jordan Cooze ${ }^{1}$, Dana El Assad ${ }^{3}$, Gilles Frache ${ }^{3}$, Wei Rao ${ }^{4}$, Luke B. Allen ${ }^{5}$, Zeljka Korade ${ }^{5}$, Thu TA Nguyen ${ }^{6,7}$, Rathnayake AC Rathnayake ${ }^{6,7}$, Stephanie M Cologna ${ }^{6,7}$, Owain W Howell ${ }^{1}$, Malcolm R Clench $^{2}$, Yuqin Wang ${ }^{1}$, William J Griffiths ${ }^{1 *}$.

${ }^{1}$ Swansea University Medical School, Singleton Park, Swansea, SA2 8PP, Wales, UK.

${ }^{2}$ Centre for Mass Spectrometry Imaging, Biomolecular Research Centre, Sheffield Hallam University, Howard Street, Sheffield, S1 1WB, UK.

${ }^{3}$ Luxembourg Institute of Science and Technology, Materials Research and Technology (MRT), L-4422 Belvaux, Luxembourg.

${ }^{4}$ Waters Corporation, European Application Laboratory, Stamford Avenue, Altrincham Road, Wilmslow, SK9 4AX, UK.

${ }^{5}$ Departments of Pediatrics and Biochemistry and Molecular Biology, University of Nebraska Medical Center, Omaha, NE 68198, USA.

${ }^{6}$ Department of Chemistry and Laboratory of Integrated Neuroscience, University of Illinois at Chicago, Chicago, IL 60607, USA.

${ }^{7}$ Laboratory of Integrative Neuroscience, University of Illinois at Chicago, Chicago, IL 60607, USA.

* Corresponding author: William J Griffiths

Email: w.j.griffiths@swansea.ac.uk

ORCIDs: RA, 0000-0001-5136-5921; EY, 0000-0001-9971-1950; MFW, 0000-0003-4107-5941; JN, 0000-0003-4848-7391; DEA, 0000-0001-7454-4236; GF, 0000-0003-0069-9475; LBA, 0000-0002-70433376; ZK, 0000-0002-8690-4507; TTAN, 0000-0001-8617-3305; RACR, 0000-0001-8115-2812; SMC, 0000-0002-3541-3361; OWH, 0000-0003-2157-9157; MRC, 0000-0002-0798-831X; YW, 0000-00023063-3066; WJG, 0000-0002-4129-6616.

\section{Keywords}

Mass Spectrometry Imaging; Quantification; MALDI; Brain; Derivatisation; Cholesterol; Myelin, Sterol; Development; Niemann-Pick disease; 
bioRxiv preprint doi: https://doi.org/10.1101/2020.11.06.369447; this version posted November 7, 2020. The copyright holder for this preprint (which was not certified by peer review) is the author/funder, who has granted bioRxiv a license to display the preprint in perpetuity. It is made available under aCC-BY 4.0 International license.

\section{Summary}

Despite being a critical molecule for neurobiology and brain health, mass spectrometry imaging (MSI) of cholesterol has been under reported compared to other lipids, due to the difficulty in ionising the sterol molecule. In the present work we have employed an on-tissue enzyme-assisted derivatisation strategy to improve detection of cholesterol in brain tissue sections. We report distribution and levels of cholesterol across specific brain structures of the mouse brain, in a model of Niemann-Pick type C1 (NPC1) disease, and during brain development. MSI revealed how cholesterol changes during development and that in the adult is highest in pons and medulla of the brain stem. Cholesterol was significantly reduced in the corpus callosum and other brain regions in the Npc1 null mouse, confirming hypomyelination at the molecular level. Our study demonstrates the potential of MSI to the study of sterols in neuroscience.

\section{Introduction}

Cholesterol is the most abundant individual molecular specie in plasma membranes of animals (Steck \& Lange, 2018) accounting for approximately $20-25 \%$ of the lipid molecules in the plasma membrane of most cells (Dietschy \& Turley, 2004), with only a small proportion of cellular cholesterol embedded in organelle bilayers (van Meer et al., 2008). Within membranes, cholesterol influences bilayer fluidity and permeability as well as lipid and protein sorting in membrane trafficking (Simons \& Ikonen, 2000, Maxfield \& van Meer, 2010). In brain, cholesterol makes up about $15 \%$ of the dry weight of white matter (WM) and is a major component of myelin sheaths that protect and insulate neuronal axons and are required for the fast transduction of neuronal signals (Brady et al., 2012, Lajtha et al., 2010). However, to date, little is known about how sterol concentrations vary in different anatomical locations or at sites of focal pathology (Almeida et al., 2015).

Cholesterol is metabolised to oxysterols, steroid hormones and bile acids (Russell, 2003). These metabolic pathways are at least partially operative in brain and their metabolic products and intermediates serve as regulatory and biologically active signalling molecules (Griffiths \& Wang, 2019). In light of this, it is not surprising that impairment in sterol homeostasis and signalling have been implicated in a number of human disorders including neurodegenerative and neurodevelopmental conditions (Tabas, 2002, Björkhem et al., 2010, Porter \& Herman, 2011). Dysregulation of cholesterol homeostasis has been implicated in Alzheimer's disease (Larsson \& Markus, 2018, Picard et al., 2018) and multiple sclerosis (Chataway et al., 2014), whilst inborn errors of cholesterol metabolism and transport can result in neurological disorders (Kanungo et al., 2013), such as Smith-Lemli-Opitz syndrome (SLOS, 7-dehydrocholesterol reductase deficiency) and Niemann-Pick disease types C1 and C2 (NPC1 and NPC2), respectively.

Traditionally, cholesterol analysis in tissue begins with homogenisation followed by lipid extraction, leading to loss of spatial information. To better understand sterol biochemical and physiological roles there is a need to match molecular abundance with exact location. To this end, careful dissection of specific brain regions can be coupled to classical gas chromatography (GC) - mass spectrometry (MS) and to liquid chromatography (LC) - MS (Quan et al., 2003, Heverin et al., 2004, Mast et al., 2017). An alternative method to map sterol concentrations in brain is by exploiting mass spectrometry imaging (MSI). For example, time-of-flight (ToF)-secondary ion MS (SIMS) is an MSI technique where cholesterol has been detected with high intensities, even at subcellular resolutions. However, a significant drawback with this approach is that ToF-SIMS is a surface sensitive technique and cholesterol has been shown to migrate to and crystallize at the surface, covering up all co-localizing 
species in the tissue. In the other hand, matrix-assisted laser desorption/ionisation (MALDI)-MSI has been employed to detect and identify multiple molecular species and simultaneously map their distribution in tissues sections (Caprioli et al., 1997, Norris \& Caprioli, 2013, Spengler, 2015). It can generate pixelated MS data at near-cellular resolution providing spatial mapping of protein, peptide and lipid molecules according to X-Y position on a tissue section (Niehaus et al., 2019, Dreisewerd, 2014, Rompp \& Spengler, 2013, Berry et al., 2011). MALDI-MSI has been used to image lipids in brain (Trim et al., 2008, Hankin et al., 2011, Woods \& Jackson, 2006), however, cholesterol and other sterols tend to be poorly ionised by conventional MALDI and are discriminated against compared to other lipid classes that are more abundant. Cholesterol has been detected in MALDI-MSI studies (Tobias et al., 2018), but to enhance ionisation, other desorption methods have been employed, including nanostructure-initiator MS (Patti et al., 2010), sputtered silver-MALDI (Dufresne et al., 2013, Xu et al., 2015) and silver nanoparticle-MALDI (Roux et al., 2016, Muller et al., 2017). Silver ions coordinate with carbon-carbon double bonds providing cationic adducts of sterols in the MALDI matrix. Recently, "MALDI-2"-MSI has been developed, where a post-desorption second tuneable laser has been shown to enhance the ionisation of neutral lipid species including cholesterol, allowing improved visualisation in tissue sections (Barré et al., 2019, Soltwisch et al., 2015). Alternatively, derivatisation strategies can be utilised to enhance sterol ionisation. For in-solution studies we and others have exploited enzymeassisted derivatisation for sterol analysis (EADSA) (Griffiths et al., 2013, Griffiths et al., 2016, Crick et al., 2015, Solheim et al., 2019) where the sterol molecule is reacted first with cholesterol oxidase enzyme in order to oxidise the $3 \beta$-hydroxyl group to a 3-oxo and then with Girard-P (GP) hydrazine to give a charge-tagged sterol hydrazone (Figure 1). This strategy enhances MS signal and provides unique structural information upon multistage fragmentation $\left(\mathrm{MS}^{n}\right)$ which, together with retention time and accurate mass measurements, can provide unambiguous identification, even of isomeric species. Of note, others have exploited a similar but different derivatisation strategy to visualise by MSI endogenous and synthetic steroids, already possessing an oxo function, using Girard-T hydrazine (Cobice et al., 2016, Barré et al., 2016, Cobice et al., 2013).

We have adapted the EADSA protocol to MSI in order to image cholesterol in the developing and adult mouse brain as well as in a mouse model of NPC1 disease at 30-50 $\mu \mathrm{m}$ pixel size. We demonstrate the use of isotope-labelled standards to determine the absolute quantity of cholesterol in different anatomical regions of mouse brain. A quantitative MSI of the adult wild type (WT) mouse in sagittal sections was determined in the present study identifying pons and medulla of the brain stem as the regions with highest cholesterol level. The WT mouse was compared to the NPC1 mouse model which showed a significant reduction of cholesterol in the corpus callosum, caudate-putamen, thalamus, hypothalamus, midbrain, pons, and cerebellar WM. In the WT mouse brain at birth, we show that cholesterol is highest in the pontine hind brain that will develop into the cholesterol-rich pons region in the adult. The derivatisation-based method has the potential to be expanded to other low abundance sterols, while simultaneously detecting other lipid classes, visible without derivatisation. The EADSA-MSI technology shows potential in monitoring myelination processes and can be applied to the study of pathological diseases of the WM, including Alzheimer's disease and multiple sclerosis, providing a new tool of investigation to neuroscientists.

\section{Results and Discussion}

In MALDI-MS and electrospray ionisation (ESI)-MS, cholesterol is poorly ionised and is often detected as the ammonium adduct $\left[\mathrm{M}+\mathrm{NH}_{4}\right]^{+}$at $\mathrm{m} / \mathrm{z} 404.39$ or as the dehydrated protonated molecule $[\mathrm{M}+\mathrm{H}-$ $\left.\mathrm{H}_{2} \mathrm{O}\right]^{+}$at $\mathrm{m} / \mathrm{z} 369.35$ (McDonald et al., 2007). In lipidomics studies, these peaks can be distinguished from isobaric chemical noise by LC-MS. However, in MSI studies where orthogonal separations are not 
bioRxiv preprint doi: https://doi.org/10.1101/2020.11.06.369447; this version posted November 7, 2020. The copyright holder for this preprint (which was not certified by peer review) is the author/funder, who has granted bioRxiv a license to display the preprint in perpetuity. It is made available under aCC-BY 4.0 International license.

normally available, different strategies have been put in place to enhance the ionization efficiency of "intact" cholesterol in order to chemically resolve it from the background. Successful strategies include metal adduct formation, where $\mathrm{Ag}^{+}$or $\mathrm{Au}^{+}$coordinate with carbon-carbon double bonds providing cationic adducts of sterols in the MALDI matrix (Cologna, 2019). To further enhance ionization and desorption of sterols, here we exploit the EADSA method, previously used for insolution analysis of sterols. Once the sterol analyte is specifically and effectively charge-tagged by EADSA (Figure 1A), it is readily analysed by MSI, thereby allowing its detection and identification (e.g. by $\mathrm{MS}^{3}$ ) and the mapping of its distribution. The advantage of this methodology is four-fold in that it (i) greatly increases sensitivity, (ii) allows for absolute quantification, (iii) enhances structural information, and equally importantly, (iv) increases analytical specificity. Here we report how EADSA has been adapted to work on brain tissue sections for MSI studies.

\section{Quantitative MSI of Sterols in WT Mouse Brain Reveals Regional Differences in Cholesterol Content}

Initial studies were performed using sagittal mouse brain sections with a MALDI-time-of-flight (TOF) instrument (ultrafleXtreme, Bruker, Bremen, Germany). The GP-tagged cholesterol gives an intense $[\mathrm{M}]^{+}$signal, as does sprayed-on $\left[{ }^{2} \mathrm{H}_{7}\right]$ cholesterol, and dominates the resulting mass spectrum (Figure 1B). An MS Image of cholesterol distribution, normalized in each pixel to $\left[{ }^{2} \mathrm{H}_{7}\right]$ cholesterol sprayed-on standard, is shown in Figure $1 \mathrm{C}$ in the form of a spatial heat map.

To confirm the identity of the signals assigned to cholesterol, we separately carried out an $\mathrm{MS}^{3}$ $\left([\mathrm{M}]^{+} \rightarrow[\mathrm{M}-\mathrm{Py}]^{+} \rightarrow\right.$, where Py corresponds to the pyridine component of the GP-tag, see Supplemental Figure S1) analysis of the peaks at $m / z 518.41$ (cholesterol) and $m / z 525.45\left(\left[{ }^{2} \mathrm{H}_{7}\right]\right.$ cholesterol) using atmospheric pressure (AP)-MALDI on an Orbitrap MS, see Figure 2. In Supplemental Figure S1, structures of the major fragment ions observed in Figure 2 are described. The fragment ion at $m / z 163$ $\left({ }^{*} b_{3}-28\right)$ is formed by cleavage of the A/B-ring and is devoid of the CD-rings and the side-chain. It is present in $\mathrm{MS}^{3}$ spectra of both cholesterol (Figure $2 \mathrm{~A}$ ) and $\left[{ }^{2} \mathrm{H}_{7}\right]$ cholesterol (Figure 2B) authentic standards and can thus be exploited in a multiple reaction monitoring (MRM)-like experiment to confirm the location of cholesterol and $\left[{ }^{2} \mathrm{H}_{7}\right]$ cholesterol, sprayed directly on-tissue, in each pixel. Figure 2E shows that the MRM transition $518.4 \rightarrow 439.4 \rightarrow 163$ is essentially absent off-tissue, while most notably enriched in the midbrain, pons, medulla and WM tracts of the cerebellum. Conversely, Figure $2 \mathrm{~F}$ shows that the MRM transition $525.5 \rightarrow 446.4 \rightarrow 163$ is saturated off-tissue, while being quite evenly distributed on-tissue. This transition does show some variation on tissue as a consequence of matrix effects. Note, for $\mathrm{MS}^{3}$ applications current software does not allow automated normalisation of cholesterol signals to the sprayed-on internal standard.

Using $\mathrm{MS}^{1}$, areal densities were determined against a known density of sprayed-on internal standard in WT mouse brain sections, for selected brain structures (Figure 3A). The linearity of the on-tissue response of endogenous cholesterol versus the sprayed-on deuterated standard was determined by spraying eight consecutive tissue sections with $\left[{ }^{2} \mathrm{H}_{7}\right]$ cholesterol at varying known densities (Supplemental Figure S2A). Examples of calibration curves obtained on whole-brain sections and considering the cerebellum as a region of interest (ROI) are shown in Supplemental Figure S2B \& S2C, respectively. $R^{2}$ for whole brain was determined to be 0.94 and for cerebellum 0.97 . Our quantitative data reported in Figure 3B and in Table $1 \mathrm{hg} / \mathrm{mm}^{2}$, mean over five biological replicates \pm standard deviation) indicate that cholesterol abundance follows the pattern: pons $\left(681.6 \pm 123.9 \mathrm{ng} / \mathrm{mm}^{2}\right) \approx$ cerebellar white matter only $\left(652.0 \pm 119.8 \mathrm{ng} / \mathrm{mm}^{2}\right)>$ medulla $\left(613.8 \pm 111.5 \mathrm{ng} / \mathrm{mm}^{2}\right)>$ hypothalamus $\left(545.7 \pm 89.1 \mathrm{ng} / \mathrm{mm}^{2}\right) \approx$ mid brain $\left(530.6 \pm 70.6 \mathrm{ng} / \mathrm{mm}^{2}\right)>$ corpus callosum $(519.2 \pm$ $\left.55.9 \mathrm{ng} / \mathrm{mm}^{2}\right)>$ thalamus $\left(458.9 \pm 59.2 \mathrm{ng} / \mathrm{mm}^{2}\right) \approx$ caudate-putamen $\left(414.0 \pm 74.1 \mathrm{ng} / \mathrm{mm}^{2}\right)>$ whole cerebellum $\left(395.0 \pm 76.7 \mathrm{ng} / \mathrm{mm}^{2}\right)>$ olfactory traits $\left(348.5 \pm 52.4 \mathrm{ng} / \mathrm{mm}^{2}\right) \approx \operatorname{cortex}(327.8 \pm 32.5$ 
$\left.\mathrm{ng} / \mathrm{mm}^{2}\right) \approx$ hippocampus $\left(326.3 \pm 31.6 \mathrm{ng} / \mathrm{mm}^{2}\right)$. Note that cholesterol was quantified via MSI in the whole cerebellum and in its WM tracts, whereas cholesterol content in cerebellar grey matter (GM) is estimated as described below. In previous reports (Quan et al., 2003), cholesterol synthesis and concentration were found to be higher in those regions of the central nervous system (CNS) containing heavily myelinated fibre tracts such as the brain stem (medulla, pons) and the midbrain. In contrast, concentration and turnover, were significantly lower in regions such as the cerebrum and whole cerebellum (Quan et al., 2003), which mainly represent GM structures with a reduced density of myelin. Our data in Figure 3 is consistent with these observations showing a significantly lower concentration of cholesterol in whole cerebellum and forebrain structures such as the cerebral cortex, olfactory tract, and hippocampus, as compared with midbrain or brain stem structures, such as medulla and pons. In an early report (Heverin et al., 2004), it has been shown that the concentration of cholesterol in pons is 2.5 times more than in cortex, which is also in agreement with our data showing $681.6 \pm 123.9 \mathrm{ng} / \mathrm{mm}^{2}$ in pons and $327.8 \pm 32.5 \mathrm{ng} / \mathrm{mm}^{2}$ in cortex (ratio 2.1). In earlier MSI studies, cholesterol was visualised in mouse brain in coronal or horizontal sections (Sjövall et al., 2004, Dufresne et al., 2013, Tobias et al., 2018). Sagittal MS Images have the advantage that the brain stem can be easily differentiated into the midbrain, pons and medulla regions (Figure 2E and Figure $3 \mathrm{~A}$ ). These brain stem structures show high cholesterol content (Figure 3, Table 1), in agreement with previous GC-MS and LC-MS studies (Quan et al., 2003, Heverin et al., 2004).

Interestingly, the distribution of gene transcripts of late-stage cholesterol biosynthetic enzymes match to regions of high cholesterol abundance i.e. midbrain, medulla, and pons regions. Please see mRNA expression data of Dhcr24, entrez ID 74754; Dhcr7, entrez ID 13360; and Sc5d, entrez ID 235293 provided by the Allen Mouse Brain Atlas (Lein et al., 2007). Of note, the abundance of cholesterol in the corpus callosum and in the fibre tracts of the caudate-putamen mirrors the distribution of transcripts unique to myelinating oligodendrocytes that wrap around axons during development. See

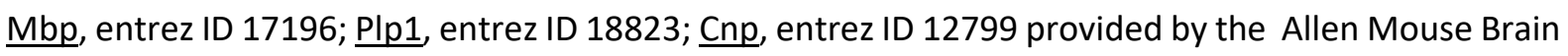
Atlas (Lein et al., 2007).

When $\mathrm{MS}^{1}$ data at high mass resolution is visualised in a peripheral sagittal section taken at a plane about $3 \mathrm{~mm}$ from the midline, the distribution of GP-derivatised cholesterol at $\mathrm{m} / \mathrm{z} 518.4103$ is clearly enhanced in specific regions of brain (Figure 4A). These are either WM tracts such as the corpus callosum and cerebellum, or brain regions (deep GM structures) containing myelinated fibres, such as the pons, medulla of the brain stem and caudate-putamen of the diencephalon. In Figure 4 the selected sagittal plane does not include midbrain but shows interesting hippocampal features described below.

Notably, using our method for on-tissue cholesterol derivatisation, and in contrast to ToF-SIMS, other lipids can be mapped simultaneously particularly when experiments are carried out under atmospheric pressure ionisation (i.e. AP-MALDI - Orbitrap and desorption-ESI (DESI) - Q-TOF). To show the potential of our approach, we report the MS image of PC 32:0 at $\mathrm{m} / z 734.5702$ (about $1 \mathrm{ppm}$ deviation from the theoretical $\mathrm{m} / \mathrm{z}$ ), normalized to $\left[{ }^{2} \mathrm{H}_{7}\right]$ cholesterol sprayed-on standard (Figure $4 \mathrm{~B}$ ), but many other peaks could be similarly imaged. Please note that the peak at $m / z 734.5702$ could be similarly assigned to PE 35:0. However, phospholipids containing fatty acids with an odd number of carbon atoms are minor species in animals.

Interestingly in Figure 4A, a continuous gradient of cholesterol concentration is observed in the forebrain, going out from the corpus callosum, where cholesterol is at an areal density of about 520 $\mathrm{ng} / \mathrm{mm}^{2}$, decreasing on moving through the overlying layers of the neocortex correlating with the higher myelination index of the corpus callosum, WM, in comparison to the cortical GM layers. Indeed, 
in the cerebral cortex, cholesterol was quantified to be about $330 \mathrm{ng} / \mathrm{mm}^{2}$ (Figure 4D shows reference anatomy). The continuous cholesterol gradient is mirrored by the distribution of the presumed phosphatidylcholine (PC 32:0) in the same brain regions (Figure 4B). Within the cerebellum, a structure with a central component of WM surrounded by partly myelinated GM, a decreasing concentration of cholesterol going from the WM of the cerebellum (CBX WM, $652.0 \pm 119.8 \mathrm{ng} / \mathrm{mm}^{2}$ ) to the granule cell layer and molecular layer of the GM can be observed (Figure 4D shows reference anatomy). Note that cholesterol density in cerebellar GM can be estimated ( $C B X-C B X W M=C B X G M$ ) to be about $260 \mathrm{ng} / \mathrm{mm}^{2}$. Here, the cholesterol smooth gradient contrasts with the step gradient shown by PC 32:0 (Figure 4B) which is deficient in the granule cell layer of the cerebellum but more evident in the molecular layer. Differential gradients for both cholesterol and PC 32:0 can be observed also in the Ammon's horn and the dentate gyrus of the hippocampal formation. Figure 4B shows that PC 32:0 is deficient in the pyramidal layer of the Ammon's horn and in the granule cell layer of the dentate gyrus while it is more evident in the strata oriens, radiatum and lacunosum-moleculare of the Ammon's Horn as well as in the molecular and polymorph layers of the dentate gyrus (Figure 4D shows reference anatomy). The step gradient of PC 32:0 demonstrates the outlines of the Ammon's horn and of the dentate gyrus, while the cholesterol distribution gradient is more continuous across these structures (Figure 4A). Indeed cholesterol, although being more concentrated in the myelin sheaths of the WM, is a key component of all membranes and, therefore, is present throughout the brain. Moreover, cholesterol is by far the major representative of its class, with other sterols present at comparatively low abundance and not exerting any known structural function in membranes. On the contrary membrane phospholipids such as PC, have high structural diversity (Harayama \& Riezman, 2018) and may show both a continuous gradient (as in the cortex), or a step gradient (as in cerebellum and hippocampus) for an individual molecular specie, even within layers of the same brain structure.

The EADSA-MALDI-MSI quantitative assessment of cholesterol areal density in defined brain regions of the WT mouse can be compared with measurements previously obtained with a similar but different experimental approach exploiting low-spatial resolution $(400 \mu \mathrm{m}$ pixel size) Liquid Extraction for Surface Analysis (LESA) i.e. EADSA-LESA-LC-MS (Yutuc et al., 2020). Table 1 reports the values obtained and their standard deviations, in each defined brain region of WT mouse, for both the present and the EADSA-LESA-LC-MS study. The agreement between the studies is also reported. The agreement was $>90 \%$ for very homogenous regions such as cortex and thalamus, it was about $80 \%$ for caudate-putamen, hippocampus, pons and cerebellar white matter, and was $>67 \%$ for heterogeneous structures such as midbrain and medulla.

\section{Neuroimaging of Cholesterol in the Developing Mouse}

To illustrate how our EADSA-MSI method can be used to monitor brain cholesterol distribution during development we compared tissues from mice at 1-day and 10-weeks. At birth, myelination is in its very early stage, while at 10 weeks is nearly completed (Goffinet \& Rakic, 2000). During development, the cholesterol content in the whole brain goes from about $4 \mathrm{mg} / \mathrm{g}$ at birth up to about $15 \mathrm{mg} / \mathrm{g}$ in the adult at 26-weeks (Dietschy, 2009), and comes from local synthesis only (Dietschy \& Turley, 2004). During the first three weeks of life, when myelin sheaths are being generated, the rates of cholesterol synthesis and accumulation in brain are high at about $250 \mu \mathrm{g} /$ day (Quan et al., 2003), and drop rapidly beyond three weeks of age (Dietschy, 2009). Body growth is completed at about 7 weeks, with most strains reaching sexual maturity between $6-8$ weeks. Therefore, we can use the arbitrary but reasonable date of postnatal week 10 as the definition of young adult mouse (Hedrich \& Bullock, 2012). 
bioRxiv preprint doi: https://doi.org/10.1101/2020.11.06.369447; this version posted November 7, 2020. The copyright holder for this preprint (which was not certified by peer review) is the author/funder, who has granted bioRxiv a license to display the preprint in perpetuity. It is made available under aCC-BY 4.0 International license.

EADSA-MSI was employed to visualise cholesterol distribution in the mouse brain at 1-day and at 10weeks (Figure 5). We compared MSI of cholesterol with Luxol Fast Blue (LFB) chemical stain and Cresyl Violet (CV; as counterstaining) histology, a traditional but nonspecific histological stain for myelin (Kluver \& Barrera, 1953), as illustrated in Figure 5C (newborn) and Figure 5D (10-weeks). Figure 5E shows the MSI of cholesterol distribution at 1-day around the time when oligodendrocytes start to contribute to cholesterol synthesis (Saher \& Stumpf, 2015) and Figure 5F shows the distribution at 10weeks.

As measured by quantitative EADSA-MSI, the newborn (Figure 5G, Supplemental Table S1) shows the highest cholesterol level in the pontine hindbrain $\left(193.4 \pm 28.4 \mathrm{ng} / \mathrm{mm}^{2}\right)$ and in the medullary and pontomedullary hindbrain $\left(180.3 \pm 25.6 \mathrm{ng} / \mathrm{mm}^{2}\right)$ that will develop into the cholesterol-rich pons and medulla of the adult mouse (Figure 3B) (Goffinet \& Rakic, 2000). The lowest levels of cholesterol are detected in the telencephalic vesicle (Tel, $111.7 \pm 13.9 \mathrm{ng} / \mathrm{mm}^{2}$ ) and in the Pallium (125.1 \pm 15.3 $\mathrm{ng} / \mathrm{mm}^{2}$ ) which will develop into the cortex, olfactory tracts, hippocampus and caudate-putamen (Goffinet \& Rakic, 2000). Similar to the newborn, these are regions with low cholesterol in the adult (Figure 3, Table 1) except for the caudate-putamen which contains some fibre tracts in the adult that are not yet formed in the newborn (Goffinet \& Rakic, 2000). The pro-hypothalamic region (peduncular hypothalamus), which begets the adult hypothalamus and associated fibre tracts, shows a diffused enrichment in cholesterol in the newborn (Figure 5A \& E), while the hypothalamus in the adult accumulates cholesterol only in surrounding fibres (Figure 5B \& F). A striking difference between 1day and 10-week animals is the lack of a visible corpus callosum (CC) in the newborn. In the mouse, myelination of the CC is reported to begin at 11 days after birth (Sturrock, 1980) and CC is detected by histological methods at around 16-17 days of age (Wahlsten, 1984). In contrast to the newborn, in the 10-week adult the CC is fully formed (Hedrich \& Bullock, 2012). In particular, in the adult the thicker regions of the CC show enrichment in cholesterol, namely the rostrum-genu (frontal, $504.3 \pm$ $57.7 \mathrm{ng} / \mathrm{mm}^{2}$, see Supplemental Figure S3), the body (central, $546.2 \pm 66.3 \mathrm{ng} / \mathrm{mm}^{2}$ ) and the splenium (back, $500.4 \pm 35.3 \mathrm{ng} / \mathrm{mm}^{2}$ ), while the thinnest part of the $\mathrm{CC}$, the isthmus connecting the body and the splenium is the CC structure with lowest cholesterol abundance $\left(457.8 \pm 51.2 \mathrm{ng} / \mathrm{mm}^{2}\right)$. It is reassuring that the anatomical thickness of the $\mathrm{CC}$ matches with cholesterol enrichment as determined by EADSA-MSI.

Worthy of note, the unspecific LFB myelin stain of the newborn provides little distributional information as compared to the MSI heat map for cholesterol (Figure 5C cf. 5E). Indeed, by MSI a differential distribution of cholesterol can be detected across different areas of the newborn mouse brain, which does not match the distribution of myelin as assessed by LFB, which shows a very pale and uniform staining pattern across many regions in the newborn. Conversely the comparison of MSI and LFB in the adult shows an overlap of stain and mass spectral cholesterol signal intensity. Importantly, MSI is highly sensitive and as applied here, specific for cholesterol, while the exact molecular species bound by LFB remain uncertain (Blackwell et al., 2009). The distribution of cholesterol via MSI shows some overlap with gene expression data available at the Allen Brain Atlas (Lein et al., 2007) for lineage-specific markers of myelin-producing oligodendrocytes at the perinatal stage (E18.5). See for example expression of Mbp, entrez ID 17196; Plp1, entrez ID 18823; and $\underline{\mathrm{Cnp}}$, entrez ID 12799 in the mouse at E18.5. However, the first group of neurons in developing brain are monoaminergic neurons, see for example expression of $\underline{T h}$, entrez ID 21823; Tph2, entrez ID 216343; and $\underline{D b h}$, entrez ID 13166 in the mouse at E18.5, and at P0 neurons provide their own source of cholesterol and it is likely that cholesterol synthesising and developing neurons contribute to the MS image of cholesterol in the newborn. Notably, the cholesterol distribution in the newborn mouse imaged by vacuum MALDI-TOF (Figure $5 \mathrm{E}$ ) is consistent with the image of an adjacent brain section 
bioRxiv preprint doi: https://doi.org/10.1101/2020.11.06.369447; this version posted November 7, 2020. The copyright holder for this preprint (which was not certified by peer review) is the author/funder, who has granted bioRxiv a license to display the preprint in perpetuity. It is made available under aCC-BY 4.0 International license.

produced by DESI-Q-TOF (Supplemental Figure S4E), proving the robustness of the EADSA-MSI approach.

Finally, as measured by EADSA-MSI the whole-brain areal density of cholesterol in the newborn is about $160 \mathrm{ng} / \mathrm{mm}^{2}$ while it is about $480 \mathrm{ng} / \mathrm{mm}^{2}$ in the adult at 10 weeks, showing a 3-fold increase. Our data is in good agreement with previous reports (Quan et al., 2003) where the cholesterol content in the newborn was determined to be about $4 \mathrm{mg} / \mathrm{g}$ at birth and to increase to about $10 \mathrm{mg} / \mathrm{g}$ at 10 weeks, showing a 2.5 -fold increase. In summary the present data demonstrate that EADSA-MSI can be used effectively to monitor cholesterol abundance in brain structures during development.

\section{Neuroimaging of Cholesterol in the Niemann-Pick Disease type C1 Shows a Lack of Cholesterol in Hypomyelinated Fibres Tracts}

Niemann-Pick Disease, type $\mathrm{C}$ is a neurodegenerative, lysosomal storage disorder, characterized by accumulation of unesterified cholesterol and sphingolipids in the endo-lysosomal system (Vanier, 2015). The disease is caused by mutations in the encoding region of genes either for the lysosomal transmembrane protein, NPC1 (95\% of cases) or the small cholesterol-binding soluble glycoprotein, NPC2 ( $\sim \%$ of cases) (Loftus et al., 1997, Naureckiene et al., 2000). These two proteins work together to transport cholesterol through the late endosomal-lysosomal membrane into the cytosolic and metabolically active cholesterol pool. Patients with NPC disease show extensive hypomyelination that manifest in cerebral and cerebellar atrophy as well as WM hypoplasia as detected in MRI scans (Palmeri et al., 1994).

In the present study we analysed the cholesterol content and distribution in the brain of the $\mathrm{Npc1}^{-/}$ mouse where the gene was knocked out by a naturally occurring retroposon-driven frameshift mutation (BALB/cNctr-Npc1 ${ }^{\text {m1N } / J, ~ h t t p s: / / w w w . j a x . o r g / s t r a i n / 003092) ~(M o r r i s ~ e t ~ a l ., ~ 1982, ~ S h i o ~ e t ~ a l ., ~}$ 1982, Bhuvaneswaran et al., 1982). In the brain of this mouse, at the 7-week time point, cellular dysfunction translates into loss of many large neurons. In particular, Purkinje cells of the cerebellum are particularly sensitive to NPC pathology and are largely lost in patients (Gilbert et al., 1981) and in the mouse model (Higashi et al., 1993). Moreover, the brain of the $\mathrm{Npc1}^{\%}$ mouse generally shows severe dysmyelination of fibre tracts with impairment of oligodendrocyte maturation (Saher \& Stumpf, 2015). As in patients (Palmeri et al., 1994), oligodendrocyte loss and dysmyelination may result in hypoplasia of the corpus callosum in this mouse model (German et al., 2001, German et al., 2002). When NPC1/2 proteins are lacking, cholesterol and other lipids remain in the late endosomes/lysosomes and are not transported into the endoplasmic reticulum (ER) and, therefore, sterol homeostasis is undermined by the lack of feedback regulatory mechanisms, i.e. free cholesterol accumulates in the late endosomes/lysosomes compartment while the rest of the cell perceives a shortage of sterol. Indeed, in the $\mathrm{Npc1}^{-}$mouse, sterol synthesis is not blocked by accumulating cholesterol as cholesterol overload is confined to lysosomes, consequently SREBP2 processing is constitutively active and target gene expression is maintained driving cholesterol synthesis (Liu et al., 2009). In this complicated landscape, it is important to understand the downstream effects of lysosomal cholesterol accumulation on defined brain areas, as well as on specific neuronal cell populations, in vivo. Previous work on lipid accumulation in NPC1 disease showed how several tissue are affected by changes in lipid composition (Zhou et al., 2011, Kulinski \& Vance, 2007, Liu et al., 2000, Fan et al., 2013, Liu et al., 2009, Reid et al., 2008). However, in these studies tissue lysate lipidomics was employed to obtain sensitive, specific and quantitative data at the expense of information regarding spatial distribution. Recently one MSI study has assessed lipid changes in this $\mathrm{NpC1}^{-1}$ mouse but was limited to the cerebellum (Tobias et al., 2018). 
bioRxiv preprint doi: https://doi.org/10.1101/2020.11.06.369447; this version posted November 7, 2020. The copyright holder for this preprint (which was not certified by peer review) is the author/funder, who has granted bioRxiv a license to display the preprint in perpetuity. It is made available under aCC-BY 4.0 International license.

In the present study we have exploited MSI to study the whole brain. The chosen time point was of 10-weeks when the phenotype is severe but not yet lethal: $\mathrm{Npc1}^{-1}$ mice die at an average of 84 days (12-weeks) (Liu et al., 2009). Figure 6A and 6B show the MSI spatial heat maps of cholesterol distribution in the WT and $\mathrm{NpC1}^{-1-}$ mouse brain, respectively. These heat maps can be compared with Figure $6 \mathrm{C}$ and $6 \mathrm{D}$ showing LFB/CV histological staining for myelin of corresponding adjacent brain tissue sections. For further comparison of MALDI-MSI with histology, the density of myelinated fibres in the caudate-putamen (Figures 6E and Supplemental S5A) and the number of Purkinje cells in the cerebellum (Figures $6 \mathrm{~F}$ and Supplemental S5B) of WT and $\mathrm{Npc1}^{-1-}$ mouse were determined from the histological data obtained via LFB/CV staining. Figure $6 \mathrm{G}$ shows cholesterol levels in selected brain ROI as quantified by MSI.

As with the WT mouse, cholesterol areal densities in the $\mathrm{Npc1}^{-/}$mouse were determined against a known density of sprayed-on internal standard. The quantitative data reported in Figure $6 \mathrm{G}$ and in Table 1 indicate that cholesterol abundance follows the pattern: cerebellar white matter (462.1 \pm 58.7 $\left.\mathrm{ng} / \mathrm{mm}^{2}\right) \approx$ medulla $\left(461.6 \pm 111.3 \mathrm{ng} / \mathrm{mm}^{2}\right) \approx$ pons $\left(454.2 \pm 49.5 \mathrm{ng} / \mathrm{mm}^{2}\right)>$ hypothalamus $(417.7 \pm$ $\left.50.2 \mathrm{ng} / \mathrm{mm}^{2}\right)>$ midbrain $\left(383.1 \pm 32.0 \mathrm{ng} / \mathrm{mm}^{2}\right)>$ caudate-putamen $\left(357.5 \pm 50.7 \mathrm{ng} / \mathrm{mm}^{2}\right) \approx$ thalamus $\left(352.6 \pm 51.9 \mathrm{ng} / \mathrm{mm}^{2}\right)>$ corpus callosum $\left(340.8 \pm 44.6 \mathrm{ng} / \mathrm{mm}^{2}\right) \approx$ olfactory traits $(337.5 \pm 35.2$ $\left.\mathrm{ng} / \mathrm{mm}^{2}\right) \approx$ cerebellum $\left(335.8 \pm 40.0 \mathrm{ng} / \mathrm{mm}^{2}\right)>\operatorname{cortex}\left(307.4 \pm 36.9 \mathrm{ng} / \mathrm{mm}^{2}\right)>$ hippocampus $(288.9$ $\pm 36.5 \mathrm{ng} / \mathrm{mm}^{2}$ ).

Table 1 reports cholesterol areal density values for the $\mathrm{Npc1}^{-/}$mouse as measured by EADSA-MSI and $\%$ differences compared with the WT animal. The regions showing highest reduction of cholesterol in the $\mathrm{Npc1}^{-1}$ mouse compared to the WT are the corpus callosum (34.4\%), pons (33.4\%), cerebellar white matter (29.1\%), midbrain (27.8\%), medulla (24.8\%), hypothalamus (23.5\%), thalamus (23.2\%) and caudate-putamen (13.6\%). All these differences, except for the medulla, are significant ( $p$-values are indicated in Figure $6 \mathrm{G})$.

A comparison of histological as well as MSI data in WT and $\mathrm{Npc1}^{-/-}$mouse brain reveals structural differences that can be correlated with compositional changes of cholesterol distribution and abundance. The most striking difference is in the CC. Figure $6 \mathrm{C}$ shows that the $\mathrm{CC}$ in the WT mouse is heavily myelinated and highlighted by the LFB dye. On the contrary, Figure 6D shows that the CC is apparently non-myelinated in the $\mathrm{Npc1}^{-/}$brain with the LFB stain showing this structure as mostly white. This correlates well with our MSI data where cholesterol areal density is significantly higher in the WT as compared to the Npc1\% CC (Figure 6G, ${ }^{* * *}$-value $<0.001$ ).

Other than in the CC, the significantly higher cholesterol areal density as determined by MSI in the caudate-putamen region, and in the cerebellar white matter of the WT mouse as compared to the $\mathrm{Npc1}^{-1-}$ mouse ( ${ }^{*}$ p-values $<0.05$, Figure $6 \mathrm{G}$ ), also relates to known histological markers (German et al., 2002, German et al., 2001). This prompted us to further analyse histological data by assessing the percentage of myelinated fibres in the caudate-putamen (Figures 6 E and Supplemental S5A), and the number of Purkinje cells in the cerebellar GM (Figures 6F and Supplemental S5B) of these mice.

In the caudate-putamen, myelinated fibre density assessed in LFB/CV stained sections was found to be significantly reduced in the $\mathrm{Npc}^{-1}$ mouse as compared to WT (Figures 6E and Supplemental S5A, **p-value $<0.01)$, agreeing with MSI measurement of cholesterol areal density in the same brain region (Figure $6 \mathrm{G},{ }^{*} \mathrm{p}$-value $<0.05$ ).

Focusing on the cerebellum, the MSI quantitative measurements show a statistically significant difference when cerebellar WM is considered (Figure 6G, ${ }^{*} p$-value $<0.05$ ). This data is in agreement with a previous MSI study (Tobias et al., 2018), similarly showing a reduced cholesterol signal intensity, 
as normalized by total ion current (TIC), in the cerebellum of the same $\mathrm{Npc1}^{-1-}$ mouse when compared to WT. Interestingly, there is significant reduction of the number of Purkinje cells in the GM of the $\mathrm{Npc1}^{-}$cerebellum (Figures 6F and Supplemental S5B, ${ }^{* * *} \mathrm{p}$-value $<0.001$ ). Loss of Purkinje cells is a well know phenotypic marker of NPC patients (Gilbert et al., 1981) and animal models (Higashi et al., 1993). These neuronal cells have their cell bodies residing in the cerebellar GM, but their myelinated axons establish postsynaptic connections with cerebellar deep nuclei in the WM (Goodlett \& Mittleman, 2017). Therefore, a reduction in the cholesterol content of the cerebellar WM of the Npc11- mouse could be explained in part by the loss of Purkinje cell efferent and afferent connections.

A significant reduction in the cholesterol areal density of hypothalamus, midbrain, and pons in the Npc1\%-mouse compared to WT was revealed by MSI (Figure 6G, ${ }^{*} p$-value $<0.05$ and ${ }^{* *} p$-value $<0.01$ ). Observation of the histological staining shown in Figure $6 \mathrm{C}$ and $6 \mathrm{D}$ illustrates reduced LFB stain density in these same areas of the $\mathrm{Npc1}^{-/}$mouse, correlating with MSI heatmaps of cholesterol in Figures $6 \mathrm{~A}$ and $6 \mathrm{~B}$, respectively.

\section{EADSA-MSI with Multiple Ionisation Modes and Analysers}

We assessed the robustness of our EADSA-MSI method on different mass spectrometers having different sources (vacuum-MALDI, AP-MALDI and DESI) and analysers (Q-TOF with and without ion mobility, linear TOF, Orbitrap). Our data is consistent as shown for the cholesterol distribution in adult mouse in Figures 1C, 5F, 6A, Supplemental S2A all generated by vacuum-MALDI-TOF (Bruker ultrafleXtreme), in Supplemental Figure S4A generated by MALDI-Q-IM-TOF (Waters Synapt G2), in Supplemental Figure S4C generated by DESI-Q-TOF (Waters Synapt G2), and in Figure 4A generated by AP-MALDI-Orbitrap (MassTech and ThermoFisher Scientific). Supplemental Figures S4A and S4C represents sagittal sections of different WT mice and were taken on different planes separated by about $300 \mu \mathrm{m}$. Supplemental Figure S4A is matched with the correspondent reference section from the Allen Mouse Brain Atlas (Lein et al., 2007) in Figure S4B, and Figure S4C is matched with the appropriate atlas section in Figure S4D. Altogether these data illustrate the reproducibility and robustness of our EADSA-MSI methodology.

\section{Conclusion}

The EADSA-MSI method presented provides a tool for the quantitative imaging of cholesterol in histological mouse brain tissue sections. On-tissue EADSA was successfully employed to improve the analytical power of MSI toward sterols, allowing quantitative mapping of cholesterol at pixel sizes down to $30 \mu \mathrm{m}$. Different MS platforms were utilized including vacuum-MALDI-TOF, vacuum-MALDIQ-IM-TOF, AP-MALDI-Orbitrap and DESI-Q-TOF, demonstrating the robustness of the method towards different ionization sources, analysers and detectors. With atmospheric pressure ionisation-MSI (APMALDI-Orbitrap and DESI-Q-TOF) the method allowed detection of other lipid classes (phospholipids) in parallel to derivatised sterols, thereby extending the reach of the methodology to the characterization of diverse lipid markers simultaneously. MSI is a rapidly advancing technology that can reach cellular resolution (Soltwisch et al., 2020), thereby providing information not only on structural changes but also on changes happening at the level of different cell populations. Bridging MS-based lipidomics with histopathology will allow the correlation of high sensitivity quantitative molecular information with anatomical location, opening a further window for the entry of MSI into clinical chemistry. The EADSA-MSI method described here for imaging of cholesterol directly on tissue can be easily applied to a number of scientific fields including neuroscience, pharmacology, biochemistry and pathology. Particularly, its application to the study of diseases such as Alzheimer's 
bioRxiv preprint doi: https://doi.org/10.1101/2020.11.06.369447; this version posted November 7, 2020. The copyright holder for this preprint (which was not certified by peer review) is the author/funder, who has granted bioRxiv a license to display the preprint in perpetuity. It is made available under aCC-BY 4.0 International license.

and multiple sclerosis has the potential to unveil the role of cholesterol in these important neuropathologies. 
bioRxiv preprint doi: https://doi.org/10.1101/2020 11.06.369447; this version posted November 7, 2020. The copyright holder for this preprint (which was not certified by peer review) is the author/funder, who has granted bioRxiv a license to display the preprint in perpetuity. It is made available under aCC-BY 4.0 International license.

\section{Material and Methods}

The aim of the study was to develop an MSI method suitable to map the distribution and to determine the concentration of cholesterol in different anatomical regions of mouse brain.

\section{Chemicals and Reagents}

HPLC grade methanol, propan-2-ol, acetonitrile, ethanol, xylene, industrial methylated spirit and water were from Fisher Scientific (Loughborough, UK). Glacial acetic acid was purchased from VWR (Lutterworth, UK). $\left[25,26,26,26,27,27,27-{ }^{2} \mathrm{H}_{7}\right]$ Cholesterol was from Avanti Polar Lipids (Alabaster, AL). Cholesterol oxidase from Streptomyces sp., potassium dihydrogen phosphate, Luxol Fast Blue (LFB), Cresyl Violet (CV), DPX mountant, paraformaldehyde (PFA), and $\alpha$-cyano-4-hydroxycinnamic acid (CHCA) were from Sigma-Aldrich, now Merck (Dorset, UK). GP-hydrazine was from TCI Europe (Zwijndrecht, Belgium). Lithium carbonate was from Acros Organic, now Thermo Fisher Scientific (Geel, Belgium).

\section{Experimental models}

For the present study WT and $\mathrm{Npc1}^{-}$mice were employed. Experiments were performed in accordance with University of Illinois at Chicago IACUC approved protocols. Balb/c $n p \mathrm{c}^{\text {nih }}\left(\mathrm{Npc1}^{+/-}\right)$mice were obtained from Jackson Laboratories (RRID:IMSR JAX:003092) and a breeding colony was maintained. Genotype was confirmed by PCR as previously reported (Tobias et al., 2018). At ten weeks of age, WT $\left(\mathrm{Npc1}^{+/+}\right)$and the null mutant $\left(\mathrm{Npc1}^{-/}\right)$mice were euthanized via $\mathrm{CO}_{2}$ asphyxiation followed by decapitation. All mice were males. In all cases, whole brain was removed and immediately frozen in dry ice to maintain spatial integrity and stored at $-80^{\circ} \mathrm{C}$. Details of the phenotypically normal 1-dayold newborn mouse can be found in Supplemental Methods.

\section{Tissue Sectioning}

Fresh frozen brain tissue, mounted on and only partially embedded in OCT (Optimal Cutting Temperature) compound, was cryo-sectioned using a Leica Cryostat CM1900 (Leica Microsystems, Milton Keynes, UK) at a chamber temperature of $-18^{\circ} \mathrm{C}$ into $10 \mu \mathrm{m}$-thick sections which were thawmounted onto optical microscope slides for histology or onto indium tin oxide (ITO) coated glass slides for MSI, and stored at $-80^{\circ} \mathrm{C}$ until use. ITO coated glass slides ( $8-12 \mathrm{Ohm} / \mathrm{Sq}$ ) for MSI were from Diamond Coatings (Halesowen, UK). Three sections were mounted on each glass slide, each section was separated by $100 \mu \mathrm{m}$ from the adjacent section, i.e. the nine sections in between were placed on other consecutive slides.

\section{Histology}

Tissue sections adjacent to sections analysed by MSI were thawed, fixed in PFA to preserve anatomy, and subjected to LFB histology with cresyl violet as the counterstain, essentially as described in (Kluver \& Barrera, 1953) and in Supplemental Methods. Finally, a cover slip was placed over the specimens with DPX permanent mountant. Histological data was analysed by QuPath (Bankhead et al., 2017) and ImageJ (Schneider et al., 2012) following whole section digitisation at 400x magnification using a Zeiss AxioScanner.

\section{Region of Interest Analysis and Quantitative Morphometry}

Quantitative analysis of histological data was carried out as follows. To assess fibre myelination, the caudate-putamen ROI was outlined on the digitised images with Qupath (Supplemental Figure S5A). Images of defined ROI were cropped and converted into an 8-bit format with ImageJ to mark and measure specific areas. The threshold was adjusted to exclude cell nuclei and automatically outline WM areas exclusively, and total WM area was measured per section. These data were used to 
bioRxiv preprint doi: https://doi.org/10.1101/2020.11.06.369447; this version posted November 7, 2020. The copyright holder for this preprint (which was not certified by peer review) is the author/funder, who has granted bioRxiv a license to display the preprint in perpetuity. It is made available under aCC-BY 4.0 International license.

calculate the percentage of myelinated fibres in the selected ROI (Figure 6E). Cerebellar area and length of the Purkinje cell layer were also defined with Qupath (Supplemental Figure S5B) and Purkinje cells were manually counted to determine cell linear density (Figure 6F). Statistical analysis was carried out on GraphPad 8.1. A Shapiro-Wilk test was employed to confirm normality followed by an unpaired $t$-test to assess statistical significance of measured differences.

\section{Stereology}

Stereological methods were employed to identify ROI within mouse brain sagittal tissue sections. The defined ROI where employed to analyse both the MSI and the histology data. For determination of ROI we referred to the Allen Mouse Brain Atlas (sagittal sections, P56, https://atlas.brainmap.org/atlas?atlas=2) (Lein et al., 2007). Firstly, the mouse brain was sectioned through a sagittal plane. Then stained sagittal sections were matched with images in the corresponding reference atlas (Allen Institute for Brain Science). The shape of the fibres tracts as detected by LFB was used to identify the correct atlas reference image having a comparable distance from the midline. Then the LFB/CV stained sections and the MSI heat maps were overlaid together with the appropriate reference atlas images, and anatomical regions identified were outlined with dashed lines defining ROI (Figures $3 \mathrm{~A}$, 6C-D, and Supplemental S6).

For MALDI-MSI data analysis of the adult mouse, three sagittal sections at about $1.3 \mathrm{~mm} \pm 300 \mu \mathrm{m}$ distance from the midline were employed. The three chosen sections were taken at sagittal planes separated by $100 \mu \mathrm{m}$. For histology data analysis we employed sections adjacent to MSI on the left and on the right for a total of 6 sections per mouse that covered the area $1.3 \mathrm{~mm} \pm 400 \mu \mathrm{m}$ distant from the midline. The AP-MALDI data in Figure 4 was an exception and obtained on a more peripheral section (about $3 \mathrm{~mm}$ from the midline). The mouse brain atlas images (credit: Allen Institute) employed as reference were: Adult Mouse, P56, Sagittal, Images 13-16 of 21 ids $=\underline{100883818}$, $\underline{100883869}, \underline{100883867}, \underline{100883888}$ (Lein et al., 2007).

For MALDI-MSI data analysis of the newborn mouse, four consecutive sagittal sections at about 0.6 $\mathrm{mm} \pm 100 \mu \mathrm{m}$ from the midline were employed. For histology, two sections adjacent on the far left and on the far right of the series of four used for MSI were employed. The newborn mouse brain atlas image (credit: Allen Institute) employed as reference was Developing Mouse, E18.5, Sagittal, Image 16 of $19 \mathrm{id}=\underline{100740373}$ (Lein et al., 2007).

\section{Deposition of Internal Standard and On-Tissue EADSA}

This was performed as described by (Yutuc et al., 2020) with minor modifications. Frozen mouse brain sections mounted on a ITO coated glass slide were transferred under dry ice from the $-80^{\circ} \mathrm{C}$ freezer to a vacuum desiccator in which the pressure was reduced to 0.1 bar allowing the tissue to dry for 15 min. Afterwards, $\left[{ }^{2} \mathrm{H}_{7}\right]$ cholesterol $(200 \mathrm{ng} / \mu \mathrm{L}$ in ethanol) was sprayed from a SunCollect automated pneumatic sprayer (SunChrom, Friedrichsdorf, Germany supplied by KR Analytical Ltd, Cheshire, UK) at a flow rate of $20 \mu \mathrm{L} / \mathrm{min}$ at a linear velocity of $900 \mathrm{~mm} / \mathrm{min}$ with $2 \mathrm{~mm}$ line distance and height of $30 \mathrm{~mm}$ from the section in a series of 18 layers. The resulting density of the deuterated standard was $40 \mathrm{ng} / \mathrm{mm}^{2}$ (see below). The sprayer was thoroughly flushed with about $2 \mathrm{~mL}$ of methanol after which

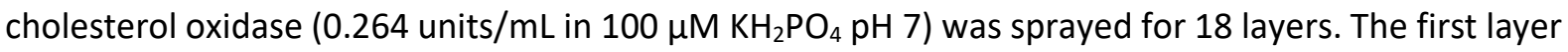
was applied at $10 \mu \mathrm{L} / \mathrm{min}$, the second at $15 \mu \mathrm{L} / \mathrm{min}$, then all the subsequent layers at $20 \mu \mathrm{L} / \mathrm{min}$ to give an enzyme density of 0.05 munits $/ \mathrm{mm}^{2}$. Thereafter, the enzyme-coated slide was placed on a custom-made dry PTFE bed in a glass staining jar $(11 \mathrm{~cm} \times 11 \mathrm{~cm} \times 7.5 \mathrm{~cm})$ above $30 \mathrm{~mL}$ of warm water $\left(37^{\circ} \mathrm{C}\right)$, then incubated at $37^{\circ} \mathrm{C}$ for $1 \mathrm{hr}$. Subsequently, the slide was removed, and the tissue was dried in a vacuum desiccator for $15 \mathrm{~min}$ as described above. GP ( $5 \mathrm{mg} / \mathrm{mL}$ in $70 \%$ methanol, $5 \%$ acetic acid) 
bioRxiv preprint doi: https://doi.org/10.1101/2020.11.06.369447; this version posted November 7, 2020. The copyright holder for this preprint (which was not certified by peer review) is the author/funder, who has granted bioRxiv a license to display the preprint in perpetuity. It is made available under aCC-BY 4.0 International license.

was sprayed on the dried slide with the same spray parameters as used for spraying of cholesterol oxidase. The resulting GP density was $1.00 \mu \mathrm{g} / \mathrm{mm}^{2}$. The slide was then placed in the custom-made humidity chamber as above containing $10 \mathrm{~mL}$ of pre-warmed $\left(37^{\circ} \mathrm{C}\right) 50 \%$ methanol, $5 \%$ acetic acid and incubated at $37^{\circ} \mathrm{C}$ for $1 \mathrm{hr}$. The slide was removed and dried in a vacuum desiccator as above, then stored in a cold room $\left(4^{\circ} \mathrm{C}\right)$ until MSI analyses. DESI-MSI experiments were performed without any further pre-treatment. For MALDI-MSI, on the next day the desiccator was allowed to reach room temperature, and then the slide was removed and sprayed with CHCA MALDI matrix. CHCA was sprayed from a HTX TM-Sprayer (HTX Technologies, NC, USA) at $5 \mathrm{mg} / \mathrm{mL}$ in water:propan-2ol:acetonitrile $(3: 4: 3, \mathrm{v}: \mathrm{v}: \mathrm{v})$ at a flow rate of $80 \mu \mathrm{L} / \mathrm{min}$ and a linear velocity of $1200 \mathrm{~mm} / \mathrm{min}$, with 2 $\mathrm{mm}$ line distance and a criss-cross deposition method which alternates vertical and horizontal passes, for a total of 8 , with an offset of $1 \mathrm{~mm}$, resulting in a matrix density of $1.33 \mu \mathrm{g} / \mathrm{mm}^{2}$. The sprayer nozzle was heated at $70^{\circ} \mathrm{C}$ to enhance solvent evaporation rate.

MSI

Following EADSA treatment, tissues sections were analysed using different mass spectrometers. Optimized instrumental parameters are described below.

\section{Vacuum MALDI-TOF-MSI}

Experiments were carried out on an ultrafleXtreme MALDI TOF/TOF mass spectrometer (Bruker Daltonics, Bremen, Germany) equipped with a Smartbeam ${ }^{\text {TM }}$ Nd:YAG laser emitting at $355 \mathrm{~nm}(2 \mathrm{kHz})$ and operated in the reflectron mode and positive polarity. Each mass spectrum was automatically acquired using the auto-execute method in FlexControl (Bruker) software in the range of $m / z 400-$ 1000. Pixel size was set at $50 \mu \mathrm{m}$ using flexImaging 4.1 software (Bruker), setting laser focus to "small". Laser power was tuned to optimise signal to noise $(\mathrm{S} / \mathrm{N})$ ratio without distortions of the baseline at $80 \%$ of maximum with Global Offset at $5 \%$, Attenuator Offset at $40 \%$, Attenuator Range at $40 \%$. These parameters result in a diameter of the laser spot of about $50 \mu \mathrm{m}$, according to factory specifications and as verified by visual inspection with the instrument camera. Extraction voltages were as follows: IS1 $20.00-19.92$ kV, IS2 $17.90-17.82$ kV, Lens $8.50-8.53$ kV, Rfl $21.10-20.99$ kV, Rfl2 10.95-10.89 $\mathrm{kV}$. Reflector gain was set at 3.0X. Pulsed Ion Extraction was timed at $160 \mathrm{~ns}$. A gated ion suppression was applied up to $m / z$ 375. Each raster was sampled with 200 shots in 5 steps for a total of 1000 shots per raster. Total acquisition time was typically about $11.5 \mathrm{hr}$ for a total of $\sim 27000$ positions and a file size of $24000 \mathrm{MB}$. The MALDI instrument was calibrated using a mixture of phosphatidylcholine and lysophosphatidylcholine (Avanti Polar Lipids) of known composition and having masses in the range of interest. After measurement, imaging spectra were re-calibrated using the batch process in flexAnalysis. On-tissue, mass accuracy was typically within $\sim 100 \mathrm{ppm}$ of the theoretical mass. Data were analysed and visualized using flexImaging 3.0 (Bruker), and SCiLS Lab 2014b (SCiLS, Bremen, Germany) without any processing step. Data were visualized using normalization to $\left[{ }^{2} \mathrm{H}_{7}\right]$ cholesterol at $m / z$ 525.5. Mass selection windows for ion of interests were chosen with a width of $\pm 0.25 \mathrm{Da}$ in flexImaging 3.0 and of $\pm 0.125 \%$ in SCiLS Lab 2014b. A mass resolution (full width at half-maximum) of $\sim \mathrm{M} / \Delta \mathrm{M} 20000$ was typically achieved in a single pixel. An optical image of each tissue section was acquired prior to the MS acquisition by means of a flatbed scanner.

\section{AP-MALDI-MSI}

MSI experiments were carried out in the positive-ion mode with an Orbitrap Elite ${ }^{\mathrm{TM}}$ Hybrid Ion TrapOrbitrap Mass Spectrometer (ThermoFisher Scientific) coupled with an AP-MALDI UHR Source (MassTech, Maryland USA, supplied by KR Analytical Ltd) equipped with a Nd:YAG laser emitting at $355 \mathrm{~nm}$. Full scan mode (MS ${ }^{1}$ ) imaging analysis was performed with $m / z$ measurement in the Orbitrap over the $m / z$ range of $400-1200$ at 60,000 resolution (FWHM at $m / z 400$ ), MALDI laser energy was set at $45 \%$ of maximum and frequency was $1.5 \mathrm{kHz}$. Data were acquired in Constant Speed Raster 
bioRxiv preprint doi: https://doi.org/10.1101/2020.11.06.369447; this version posted November 7, 2020. The copyright holder for this preprint (which was not certified by peer review) is the author/funder, who has granted bioRxiv a license to display the preprint in perpetuity. It is made available under aCC-BY 4.0 International license.

(CSR) mode at a scan speed of $2.8 \mathrm{~mm} / \mathrm{min}$ and a pixel size of $30 \mu \mathrm{m}$. Capillary temperature was $450^{\circ} \mathrm{C}$, voltage was $3 \mathrm{kV}$, injection time was $400 \mathrm{~ms}$, and a lock mass for ${ }^{2}\left[\mathrm{H}_{7}\right]$ cholesterol at $m / z 525.4544$ was employed. The acquisition of one mouse brain tissue section was achieved in about 15 hours for a total of about 90,000 positions and a file size of about $6 \mathrm{~GB}$. In MS ${ }^{3}$ experiments, the MALDI laser energy was set at $14 \%$ and frequency was $1.5 \mathrm{kHz}$. Data were acquired in CSR mode at a scan speed of $3 \mathrm{~mm} / \mathrm{min}$ and a pixel size of $40 \mu \mathrm{m}$. Capillary temperature was $350^{\circ} \mathrm{C}$, voltage was $3.5 \mathrm{kV}$, and injection time was $300 \mathrm{~ms}$. In the linear ion trap (LIT), precursor ions were isolated and fragmented with an isolation width of 2 and an arbitrary collision induced dissociation (CID) energy of $35 \%$. The most intense fragment ion produced in $\mathrm{MS}^{2}$ was selected with an isolation width of 2 and fragmented with a CID energy of $40 \%$ to produce an $\mathrm{MS}^{3}$ spectrum. $\mathrm{MS}^{3}$ fragmentation spectra of cholesterol and ${ }^{2}\left[\mathrm{H}_{7}\right]$ cholesterol were acquired in each pixel. The $\mathrm{MS}^{3}$ transition for cholesterol was $518.4 \rightarrow 439.4 \rightarrow$. The $\mathrm{MS}^{3}$ transition for ${ }^{2}\left[\mathrm{H}_{7}\right]$ cholesterol was $525.4 \rightarrow 446.4 \rightarrow$.

Data were analysed and visualized using ImageQuest (ThermoFisher Scientific). Alternatively, after exporting the file into an imzml format, data were analysed by MSiReader (Bokhart et al., 2018), and SCiLS Lab 2014b (SCiLS, Bremen, Germany) without any processing step. MS ${ }^{1}$ data were normalized to the isotope-labelled $\left[{ }^{2} \mathrm{H}_{7}\right]$ cholesterol at $m / z$ 525.454. The ions of interests were extracted with a width of $7 \mathrm{mDa}$ for the full scan experiment and 0.3 Da for the $\mathrm{MS}^{3}$ experiment.

\section{MALDI-Q-IM-TOF MSI}

Experiments were carried out on two Synapt G2-Si instruments (Waters, Wilmslow, UK) exploiting Waters HDI 1.4 software. The same software was employed for image visualization. Images were generated from spectra acquired in the positive ion mode in the $\mathrm{m} / \mathrm{z}$ range $400-1000$. The laser frequency was $1 \mathrm{kHz}$, and power was kept at 100 arbitrary units. Scan time was $0.5 \mathrm{sec}$ and pixel size was $50 \mu \mathrm{m}$. IMS cell Wave Velocity was from 1000 to $300 \mathrm{~m} / \mathrm{s}$, and Transfer Wave Velocity was 281 $\mathrm{m} / \mathrm{s}$. In all experiments the cholesterol signal was measured to better than $5 \mathrm{ppm}$ mass accuracy.

\section{DESI-Q-IM-TOF MSI}

Experiments were carried out on a Synapt G2-Si (Waters, Wilmslow, UK) using Waters HDI 1.4 software. The same software was employed for image visualization. Spectra were acquired in the positive ion mode in the $\mathrm{m} / \mathrm{z}$ range $100-1200$, with a needle voltage of $4.5 \mathrm{kV}$. The DESI solvent flow rate was $1.25 \mu \mathrm{L} / \mathrm{min}$. Scan time was $0.25 \mathrm{~s}$, and pixel size was $25 \mu \mathrm{m}$. IMS cell Wave Velocity was from 1000 to $300 \mathrm{~m} / \mathrm{s}$, and Transfer Wave Velocity was $281 \mathrm{~m} / \mathrm{s}$. In all experiments the cholesterol signal was measured with a mass accuracy better than $8 \mathrm{ppm}$.

\section{Quantification}

To achieve reliable quantitative measurements, known amounts of $\left[{ }^{2} \mathrm{H}_{7}\right]$ cholesterol were sprayed ontissue prior to the EADSA process. This procedure corrects for variation in extraction efficiency, background matrix effect, and ultimately MS response. The linearity of the on-tissue response of sprayed-on $\left[{ }^{2} \mathrm{H}_{7}\right]$ cholesterol verses endogenous cholesterol was determined by spraying eight consecutive tissue sections with $\left[{ }^{2} \mathrm{H}_{7}\right]$ cholesterol at varying densities (endogenous cholesterol areal density is assumed to be constant for a given ROI across the consecutive slices, Supplemental Figure $\mathrm{S} 2 \mathrm{~A})$. Examples of calibration curves obtained on whole-brain sections and considering the cerebellum only as a ROI are shown in Supplemental Figures S2B and S2C, respectively. Quantification was made from $[\mathrm{M}]^{+}$ion signal intensities, averaged in each brain region. Brain regions of interest were defined according to Allen Mouse Brain Atlas. During cryosectioning of the sagittal brain sections, the distance from the brain midline was controlled and kept at about $1.3 \mathrm{~mm} \pm 300 \mu \mathrm{m}$ for the adult mouse (except for experiments made with AP-MALDI-MSI), and at about $0.6 \mathrm{~mm} \pm 100 \mu \mathrm{m}$ for the newborn mouse. The areal density of cholesterol in defined regions of interest was calculated by correlating signal 
bioRxiv preprint doi: https://doi.org/10.1101/2020.11.06.369447; this version posted November 7, 2020. The copyright holder for this preprint (which was not certified by peer review) is the author/funder, who has granted bioRxiv a license to display the preprint in perpetuity. It is made available under aCC-BY 4.0 International license.

intensity to that of known density of $\left[{ }^{2} \mathrm{H}_{7}\right]$ cholesterol sprayed on-tissue. All quantitative measurements were made employing SCiLS Lab MVS (2019c Core, SCilS, Germany).

\section{Statistics}

Statistical analysis was applied to the quantitative assessment of cholesterol, myelinated fibre density, and specific cell counts, in defined brain regions of WT and $\mathrm{Npc1}^{-}$mouse brain. Five WT and three $\mathrm{Npc1}^{1-}$ brains were employed, analysing three or more sections for each mouse. To determine statistical difference in cholesterol areal density between defined regions of interest in five adult WT mice, two-way ANOVA was performed with cholesterol areal density as dependent variable and mouse and brain region as factors. The interaction between mouse and brain region was used as error variance. The residuals representing the interaction deviations were approximately normally distributed. Tukey's multiple comparisons test was used to identify significant differences between brain regions.

To determine statistical differences in cholesterol areal density in defined regions of interest between WT and $\mathrm{NpC1}^{-/-}$mouse brain a Shapiro-Wilk test for normality was performed, followed by an unpaired $t$-test for significance. The analyses were performed using GraphPad Prism 8.2.1 software (GraphPad Software, Inc, CA, USA). A $P$-value of less than 0.05 was considered statistically significant. $P<0.05, *$; $P<0.01,{ }^{* *} ; P<0.001,{ }^{* * *}$. All whiskers on bar graphs represent 1 standard deviation. Note, one of the 5 control mice was not considered in the calculation of the average cholesterol areal density for the caudate-putamen as it was not sectioned on an equivalent anatomical plane.

\section{Calculations of areal densities of internal standard, cholesterol oxidase and GP-hydrazine}

To calculate areal densities of $\left[{ }^{2} \mathrm{H}_{7}\right]$ cholesterol, cholesterol oxidase and GP-hydrazine we employed the following equation:

(1) Areal density $\left(\mathrm{mg} / \mathrm{mm}^{2}\right)=$ [no. layers $x$ concentration $(\mathrm{mg} / \mathrm{mL})$ x flow rate $\left.(\mathrm{mL} / \mathrm{min})\right] /$ [spray speed $(\mathrm{mm} / \mathrm{min}) \times$ line distance $(\mathrm{mm})]$

$\left[{ }^{2} \mathrm{H}_{7}\right]$ Cholesterol in ethanol $(200 \mathrm{ng} / \mu \mathrm{L})$ was sprayed on-tissue using a SunCollect automated pneumatic sprayer at a flow rate of $0.02 \mathrm{~mL} / \mathrm{min}$, a spray speed of $900 \mathrm{~mm} / \mathrm{min}$, a line distance of 2 $\mathrm{mm}$, for 18 layers. Using (1), the areal density on brain of $\left[{ }^{2} \mathrm{H}_{7}\right]$ cholesterol was calculated to be 40 $\mathrm{ng} / \mathrm{mm}^{2}$.

The cholesterol oxidase activity was $0.264 \mathrm{U} / \mathrm{mL}$ in the sprayed solution, using eq. 1 and the same spray parameters as for the internal standards, this translates to an areal density of $0.05 \mathrm{mU} / \mathrm{mm}^{2}$.

The concentration of the chloride salt of GP sprayed on tissue was $5 \mathrm{mg} / \mathrm{mL}$, using the same spray parameters as above this translated to an areal density of $1.00 \mu \mathrm{g} / \mathrm{mm}^{2}\left(5.1 \mathrm{nmol} / \mathrm{mm}^{2}\right)$.

\section{Acknowledgements}

This work was supported by UKRI Biotechnology and Biological Sciences Research Council (BBSRC, grant numbers BB/N015932/1 to WJG/YW/OWH/MRC/JN, BB/L001942/1 to YW). RA holds a MSCACOFUND Sêr Cymru Fellowship supported by the Welsh Government and the European Regional Development Fund. Work at the Nebraska Medical Center was supported by the NIH NIMH MH110636 (National Institute of Health National Institute of Mental Health). Work at the University of Illinois at Chicago was supported by the Ara Parseghian Medical Research Fund and the Department of 
bioRxiv preprint doi: https://doi.org/10.1101/2020.11.06.369447; this version posted November 7, 2020. The copyright holder for this preprint (which was not certified by peer review) is the author/funder, who has granted bioRxiv a license to display the preprint in perpetuity. It is made available under aCC-BY 4.0 International license.

Chemistry, College of Liberal Arts and Sciences. Dr Ruth Andrew (University of Edinburgh) is thanked for advice on performing on-tissue derivatisation. We acknowledge $\mathrm{Dr}$ Rosalind John for kindly providing the CD1 mice and Bridget Allen for brain dissection (Cardiff University). Dr Tina Angerer (Luxembourg Institute of Science and Technology) is thanked for helpful discussions. We are grateful to Professor David O.F. Skibinsky (Swansea University) for providing statistical advice.

\section{Conflicts of Interest}

WJG and YW are listed as inventors on the patent "Kit and method for quantitative detection of steroids" US9851368B2. WJG, EY and YW are shareholders in CholesteniX Ltd. The funders had no role in the design of the study; in the collection, analyses, or interpretation of data; in the writing of the manuscript; or in the decision to publish the results.

\section{Figure Captions:}

Figure 1. MSI of cholesterol in WT mouse brain via on-tissue enzyme-assisted derivatisation for sterol analysis (EADSA). (A) The on-tissue EADSA process using GP reagent occurs in two steps, both proceeding at $37^{\circ} \mathrm{C}$ and at ambient pressure in a humid atmosphere. The first step requires a water humidified atmosphere and is catalysed by the enzyme cholesterol oxidase, which converts the $3 \beta$ hydroxy-5-ene group to a 3-oxo-4-ene. Once the 3-oxo-4-ene group is in place reaction with GP hydrazine proceeds rapidly in a humid atmosphere above a solution of $50 \%$ methanol containing $5 \%$ acetic acid to give a GP hydrazone. (B) A typical mass spectrum generated in an EADSA-MALDI-MSI experiment for a single pixel. The spectrum, in the $m / z$ range $500-550$, is dominated by the signals from endogenous cholesterol and of sprayed-on standard $\left[{ }^{2} \mathrm{H}_{7}\right]$ cholesterol. In each pixel, the peak at $\mathrm{m} / \mathrm{z} 518.4$ belonging to GP-derivatised brain cholesterol is normalised to the peak at $\mathrm{m} / \mathrm{z} 525.5$ belonging to GP-derivatised sprayed-on $\left[{ }^{2} \mathrm{H}_{7}\right]$ cholesterol. By correlating the normalized intensity to a colour scale (\%), an MS Image of the distribution of cholesterol across the mouse brain tissue section is created as shown in (C). (C) The MS Image is a heat map of a sagittal mouse brain tissue section showing the relative areal density of GP-derivatised cholesterol determined by MSI. MSI data were acquired on a vacuum-MALDI-TOF mass spectrometer. Data, normalized against sprayed-on $\left[{ }^{2} \mathrm{H}_{7}\right]$ cholesterol, are shown using a "jet" scale. Scale bar $2 \mathrm{~mm}$. Images were acquired at a pixel size of $50 \mu \mathrm{m}$. Isolation window width was $0.5 \mathrm{~m} / \mathrm{z}$.

Figure 2. $\mathrm{MS}^{3}$ fragmentation patterns of $(\mathrm{A})$ tissue-endogenous cholesterol and (B) sprayed-on $\left[{ }^{2} \mathrm{H}_{7}\right]$ cholesterol, in a single pixel obtained in the LIT of an AP-MALDI-Orbitrap Elite instrument after EADSA on-tissue derivatisation of a brain tissue section and of (C) cholesterol and of (D) $\left[{ }^{2} \mathrm{H}_{7}\right]$ cholesterol reference standards obtained in the LIT of an ESI-Orbitrap Elite instrument following in-solution EADSA. The $\mathrm{MS}^{3}$ spectra were obtained for the transitions $[\mathrm{M}]^{+} \rightarrow[\mathrm{M}-\mathrm{Py}]^{+} \rightarrow$. (E, F) Images of the distribution of the $\mathrm{MS}^{3}$ fragment ion at $m / z 163$ from (E) cholesterol and (F) $\left[{ }^{2} \mathrm{H}_{7}\right]$ cholesterol in a sagittal section of WT adult mouse brain.

Figure 3. Quantitation of cholesterol in WT adult mouse brain via MSI. (A) LFB/CV staining for myelin of a sagittal mouse brain section adjacent to a section undergoing MSI. Major anatomical structures were identified by comparison with the corresponding Reference Atlas of the adult mouse brain provided by the Allen Institute of Brain Science (Lein et al., 2007) and are outlined with dashed lines: olfactory traits, OLF; cortex, CTX; corpus callosum, CC; caudate-putamen, CP; thalamus, TH; hypothalamus, HY; hippocampus, HP; midbrain, MB; pons, P; medulla, MY; cerebellum, CBX; cerebellar white matter, CBX WM. (B) Areal density $\left(\mathrm{ng} / \mathrm{mm}^{2}\right)$ of cholesterol in brain regions from five WT mice, averaged over different slices (see Statistics section). Significance levels from ANOVA using Tukey's multiple comparison test are indicated for those brain regions showing significant differences. 
${ }^{*} \mathrm{P}<0.05,{ }^{* * \mathrm{P}}<0.01, * * * \mathrm{P}<0.001, * * * * \mathrm{P}<0.0001$. Values for individual mice are given by separate histogram bars. The number of dots within each bar indicates the number of sections analysed for each mouse i.e. 3. Each dot within the bars correspond to region average for each brain slice. The height of each bar represents the mean of the region average for each mouse. The error bars indicate the SD of all the sections per mouse.

Figure 4. AP-MALDI-MSI at high mass resolution of cholesterol in sagittal sections of WT adult mouse brain. The data was obtained on Orbitrap instrument. (A) Distributional heat map of cholesterol. (B) Distributional heat map of a major structural phospholipid assigned to PC 32:0. (C) Typical AP-MALDI MSI spectrum averaged over the entire MSI dataset after on-tissue EADSA derivatisation showing sterol and phospholipid (and other brain lipids) signals that can be detected simultaneously. The spectrum contains hundreds of signals that can be mapped. (D) Anatomical layering of cortex, cerebellum and hippocampus. Layers of the cortex (CTX, dark green) and of the cerebellum (CBX, yellow) are shown. Cerebellar WM is in the lobules (coloured grey) of the cerebellum (CBX) which are surrounded by the granule cell layer (dark yellow) and then by the molecular layer (light yellow). Layers of the dorsal and ventral hippocampal formation are also visible in the selected sagittal plane in both Ammon's horn (CA) and Dentate Gyrus (DG). The CA is layered into (dorsal to ventral) strata oriens (so), radiatum (sr) and lacunosum-moleculare (slm) (all in light green) with the pyramidal layer (sp, dark green) stratified between the strata oriens (so) and radiatum (sr). The DG shows the central granule cell layer (sg, dark green) in between the molecular (mo) and polymorph (po) layers (both in light green). Image credit Allen Institute for Brain Science: Adult Mouse, P56, Sagittal, Image 7 of 21 id $=\underline{100883846}$ (Lein et al., 2007). In (A, B) isolation window width was $7 \mathrm{mmu}$, pixel size was $30 \mu \mathrm{m}$, mass deviation for cholesterol was $<1 \mathrm{ppm}$ using $\left[{ }^{2} \mathrm{H}_{7}\right]$ cholesterol as a lock mass. Images normalized against sprayed-on $\left[{ }^{2} \mathrm{H}_{7}\right]$ cholesterol.

Figure 5. Quantitative MSI of cholesterol in the mouse brain at birth and at 10-weeks. In (A, C, E) 1day-old newborn and in (B, D, F) 10-week-old adult mouse. (A, B) Images from the Allen Institute of Brain Science depicting mouse brain sagittal sections with annotations of anatomical structures. The 1-day-old newborn is matched with the E18.5-day embryo atlas image (A). Pallium, Pal; Telencephalic vesicle, Tel; Diencephalon, D; Peduncular Hypothalamus, PHY; Midbrain, M; Pontine Hindbrain, PH; Pontomedullary and Medullary Hindbrain, $\mathrm{PMH}+\mathrm{MH}$; Prepontine Hindbrain, PPH. (B) Adult mouse, abbreviations as in Figure 3. (C, D) LFB/CV staining of sagittal mouse brain sections adjacent to sections undergoing MSI. The newborn mouse brain appears pale indicating lack of myelination. (E, F) MSI of cholesterol after on-tissue EADSA by a vacuum-MALDI-MS. Data, normalized against sprayed-on $\left[{ }^{2} \mathrm{H}_{7}\right]$ cholesterol, are shown using a "jet" scale. Scale bars $1 \mathrm{~mm}$. Images were acquired at a pixel size of $50 \mu \mathrm{m}$. (G) Areal density ( $\mathrm{ng} / \mathrm{mm}^{2}$ ) of cholesterol in brain regions from two newborn WT mice, each averaged over 4 slices (see Statistics section). Values for individual mice are given by separate histogram bars. The number of dots within each bar indicates the number of sections analysed for each mouse i.e. 4. Each dot within the bars correspond to region average for each brain slice. The height of each bar represents the mean of the region average for each mouse. The error bars indicate the SD of all the sections per mouse. Image credit Allen Institute: Developing Mouse, E18.5, Image 16 of $19 \mathrm{id}=\underline{100740373}$ and Adult Mouse, P56, Sagittal, Image 15 of $21 \mathrm{id}=\underline{100883867}$ (Lein et al., 2007).

Figure 6. Histology-matched quantitative MALDI-MSI data displaying cholesterol distribution and quantification in brain tissue sagittal sections of WT and $\mathrm{Npc1}^{--}$mice. (A, B) MALDI-MSI showing cholesterol distribution in WT (A), and in $\mathrm{Npc1}^{-1-}$ (B) mouse brain tissue. The cholesterol signal was normalized to the signal of sprayed-on $\left[{ }^{2} \mathrm{H}_{7}\right]$ cholesterol. Data acquired using vacuum-MALDI-TOF MS is shown using a "jet" scale. Scale bar $1 \mathrm{~mm}$. Pixel size $50 \mu \mathrm{m}$. (C, D) LFB/CV staining for myelin of 
sagittal mouse brain sections adjacent to sections undergoing MSI. Major anatomical structures were identified by comparison with the corresponding Reference Atlas of the adult mouse brain provided by the Allen Institute of Brain Science (Lein et al., 2007) and are outlined with dashed lines. Abbreviations are the same as in Figure 3. (E) Myelinated fibre density in the CP of WT and of Npc1 ${ }^{-1}$ mice as assessed in LFB/CV stained sagittal sections. (F) Purkinje cells counts in the CBX of WT and

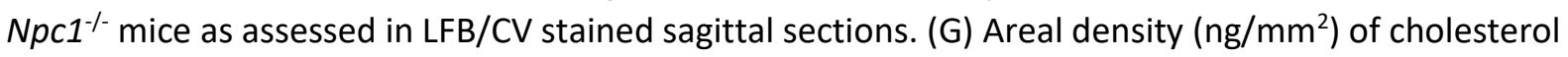
in brain regions from five WT and three $\mathrm{Npc1}^{-1-}$ mice, averaged over the biological replicates (see Statistics section. WT, $\mathrm{n}=5,3$ sections per mouse for a total of 15 measurements, $N p c 1^{-1}, \mathrm{n}=3,3$ sections per mouse for a total of 9 measurements). Significance levels from a Shapiro-Wilk test for normality followed by an unpaired $t$-test are indicated for those brain regions showing significant

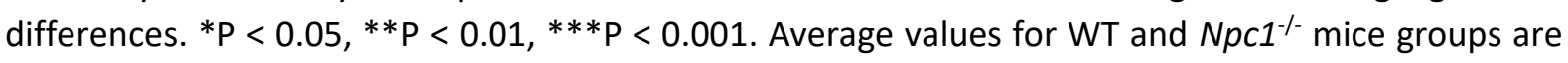
given by separate histogram bars. The number of dots within each bar indicates the number of mice analysed for each group. Each dot within the bars correspond to individual average for each mouse. The height of each bar represents the mean of the region average for each mouse group (-CTRL, or -KO). The error bars indicate the SD of all the replicates (sections) per mouse. 
Tables.

Table 1: Cholesterol areal density values in defined brain regions of WT and $\mathrm{Npc1}^{\%}$ adult mice. In the present MALDI study $n=5 \mathrm{WT}$ and $\mathrm{n}=3 \mathrm{Npc1}^{-1-}$ mice (10-weeks of age) were employed (three sections per mouse); in the LESA study $n=3$ WT mice (12 weeks of age). Averages \pm standard deviations are reported together with percentage agreement between MALDI- and LESA-MSI measurements of cholesterol levels in WT mouse brain, as are percentage differences in brain cholesterol levels as measured by MALDI MSI in WT and in $\mathrm{Npc1}^{\%}$ mice.

\begin{tabular}{|c|c|c|c|c|c|}
\hline Brain area & $\begin{array}{c}\text { MALDI MSI } \\
\text { WT } \\
\left(\mathrm{ng} / \mathrm{mm}^{2}\right)\end{array}$ & $\begin{array}{c}\text { LESA MSI } \\
\text { WT } \\
\left(\mathrm{ng} / \mathrm{mm}^{2}\right)\end{array}$ & $\begin{array}{c}\text { MALDI Vs LESA } \\
\text { WT } \\
\text { (\% Agreement) }\end{array}$ & $\begin{array}{c}\text { MALDI MSI } \\
\begin{array}{c}\mathrm{Npc1}^{--} \\
\left(\mathrm{ng} / \mathrm{mm}^{2}\right)\end{array}\end{array}$ & $\begin{array}{l}\text { MALDI MSI } \\
\text { WT Vs Npc1\%- } \\
\text { (\% Difference) }\end{array}$ \\
\hline olfactory traits & $348.5 \pm 52.4$ & & & $337.5 \pm 35.2$ & 3.2 \\
\hline cortex & $327.8 \pm 32.5$ & $305.1 \pm 53.8$ & 93.1 & $307.4 \pm 36.9$ & 6.2 \\
\hline $\begin{array}{c}\text { corpus } \\
\text { callosum }\end{array}$ & $519.2 \pm 55.9$ & & & $340.8 \pm 44.6$ & 34.4 \\
\hline $\begin{array}{l}\text { caudate- } \\
\text { putamen }\end{array}$ & $414.0 \pm 74.1$ & $366.8 \pm 4.7$ & 88.6 & $357.5 \pm 50.7$ & 13.6 \\
\hline thalamus & $458.9 \pm 59.2$ & $446.8 \pm 51.7$ & 97.4 & $352.6 \pm 51.9$ & 23.2 \\
\hline hypothalamus & $545.7 \pm 89.1$ & & & $417.7 \pm 50.2$ & 23.5 \\
\hline hippocampus & $326.3 \pm 31.6$ & $252.9 \pm 27.3$ & 77.5 & $288.9 \pm 36.5$ & 11.5 \\
\hline mid brain & $530.6 \pm 70.6$ & $356.7 \pm 74.8$ & 67.2 & $383.1 \pm 32.0$ & 27.8 \\
\hline pons & $681.6 \pm 123.9$ & $575.5 \pm 122.0$ & 84.4 & $454.2 \pm 49.5$ & 33.4 \\
\hline medulla & $613.8 \pm 111.5$ & $421.3 \pm 61.6$ & 68.6 & $461.6 \pm 111.3$ & 24.8 \\
\hline cerebellum & $395.0 \pm 76.7$ & & & $335.8 \pm 40.0$ & 15.0 \\
\hline $\begin{array}{c}\text { cerebellar } \\
\text { white matter }\end{array}$ & $652.0 \pm 119.8$ & $509.2 \pm 83.0$ & 78.1 & $462.1 \pm 58.7$ & 29.1 \\
\hline
\end{tabular}

References:

Almeida, R., Berzina, Z., Arnspang, E.C., Baumgart, J., Vogt, J., Nitsch, R., and Ejsing, C.S. (2015) Quantitative spatial analysis of the mouse brain lipidome by pressurized liquid extraction surface analysis. Analytical chemistry 87: 1749-1756.

Bankhead, P., Loughrey, M.B., Fernández, J.A., Dombrowski, Y., McArt, D.G., Dunne, P.D., McQuaid, S., Gray, R.T., Murray, L.J., Coleman, H.G., James, J.A., Salto-Tellez, M., and Hamilton, P.W. (2017) QuPath: Open source software for digital pathology image analysis. Scientific Reports 7: 16878.

Barré, F.P., Flinders, B., Garcia, J.P., Jansen, I., Huizing, L.R., Porta, T., Creemers, L.B., Heeren, R.M., and Cillero-Pastor, B. (2016) Derivatization Strategies for the Detection of Triamcinolone Acetonide in Cartilage by Using Matrix-Assisted Laser Desorption/Ionization Mass Spectrometry Imaging. Anal Chem 88: 12051-12059.

Barré, F.P.Y., Paine, M.R.L., Flinders, B., Trevitt, A.J., Kelly, P.D., Ait-Belkacem, R., Garcia, J.P., Creemers, L.B., Stauber, J., Vreeken, R.J., Cillero-Pastor, B., Ellis, S.R., and Heeren, R.M.A. (2019) Enhanced Sensitivity Using MALDI Imaging Coupled with Laser Postionization (MALDI2) for Pharmaceutical Research. Analytical chemistry 91: 10840-10848.

Berry, K.A., Hankin, J.A., Barkley, R.M., Spraggins, J.M., Caprioli, R.M., and Murphy, R.C. (2011) MALDI imaging of lipid biochemistry in tissues by mass spectrometry. Chem Rev 111: 64916512. 
bioRxiv preprint doi: https://doi.org/10.1101/2020.11.06.369447; this version posted November 7, 2020. The copyright holder for this preprint (which was not certified by peer review) is the author/funder, who has granted bioRxiv a license to display the preprint in perpetuity. It is made available under aCC-BY 4.0 International license.

Bhuvaneswaran, C., Morris, M.D., Shio, H., and Fowler, S. (1982) Lysosome lipid storage disorder in NCTR-BALB/C mice. III. Isolation and analysis of storage inclusions from liver. Am J Pathol 108: 160-170.

Björkhem, I., Leoni, V., and Meaney, S. (2010) Genetic connections between neurological disorders and cholesterol metabolism. Journal of lipid research 51: 2489-2503.

Blackwell, M.L., Farrar, C.T., Fischl, B., and Rosen, B.R. (2009) Target-specific contrast agents for magnetic resonance microscopy. Neuroimage 46: 382-393.

Bokhart, M.T., Nazari, M., Garrard, K.P., and Muddiman, D.C. (2018) MSiReader v1.0: Evolving OpenSource Mass Spectrometry Imaging Software for Targeted and Untargeted Analyses. Journal of The American Society for Mass Spectrometry 29: 8-16.

Brady, S.T., Siegel, G.J., Albers, R.W., and Price, D.L., (2012) Basic neurochemistry : principles of molecular, cellular and medical neurobiology. Academic, Oxford.

Caprioli, R.M., Farmer, T.B., and Gile, J. (1997) Molecular imaging of biological samples: localization of peptides and proteins using MALDI-TOF MS. Anal Chem 69: 4751-4760.

Chataway, J., Schuerer, N., Alsanousi, A., Chan, D., MacManus, D., Hunter, K., Anderson, V., Bangham, C.R.M., Clegg, S., Nielsen, C., Fox, N.C., Wilkie, D., Nicholas, J.M., Calder, V.L., Greenwood, J., Frost, C., and Nicholas, R. (2014) Effect of high-dose simvastatin on brain atrophy and disability in secondary progressive multiple sclerosis (MS-STAT): a randomised, placebo-controlled, phase 2 trial. The Lancet 383: 2213-2221.

Cobice, D.F., Livingstone, D.E., Mackay, C.L., Goodwin, R.J., Smith, L.B., Walker, B.R., and Andrew, R. (2016) Spatial Localization and Quantitation of Androgens in Mouse Testis by Mass Spectrometry Imaging. Anal Chem 88: 10362-10367.

Cobice, D.F., Mackay, C.L., Goodwin, R.J., McBride, A., Langridge-Smith, P.R., Webster, S.P., Walker, B.R., and Andrew, R. (2013) Mass spectrometry imaging for dissecting steroid intracrinology within target tissues. Anal Chem 85: 11576-11584.

Cologna, S.M., (2019) Mass Spectrometry Imaging of Cholesterol. In: Cholesterol Modulation of Protein Function: Sterol Specificity and Indirect Mechanisms. A. Rosenhouse-Dantsker \& A.N. Bukiya (eds). Cham: Springer International Publishing, pp. 155-166.

Correa-Cerro, L.S., Wassif, C.A., Kratz, L., Miller, G.F., Munasinghe, J.P., Grinberg, A., Fliesler, S.J., and Porter, F.D. (2006) Development and characterization of a hypomorphic Smith-Lemli-Opitz syndrome mouse model and efficacy of simvastatin therapy. Human Molecular Genetics 15: 839-851.

Crick, P.J., William Bentley, T., Abdel-Khalik, J., Matthews, I., Clayton, P.T., Morris, A.A., Bigger, B.W., Zerbinati, C., Tritapepe, L., luliano, L., Wang, Y., and Griffiths, W.J. (2015) Quantitative Charge-Tags for Sterol and Oxysterol Analysis. Clinical Chemistry 61: 400.

Dietschy, J.M. (2009) Central nervous system: cholesterol turnover, brain development and neurodegeneration. Biol Chem 390: 287-293.

Dietschy, J.M., and Turley, S.D. (2004) Thematic review series: brain Lipids. Cholesterol metabolism in the central nervous system during early development and in the mature animal. J Lipid Res 45: 1375-1397.

Dreisewerd, K. (2014) Recent methodological advances in MALDI mass spectrometry. Anal Bioanal Chem 406: 2261-2278.

Dufresne, M., Thomas, A., Breault-Turcot, J., Masson, J.-F., and Chaurand, P. (2013) Silver-Assisted Laser Desorption Ionization For High Spatial Resolution Imaging Mass Spectrometry of Olefins from Thin Tissue Sections. Analytical Chemistry 85: 3318-3324.

Fan, M., Sidhu, R., Fujiwara, H., Tortelli, B., Zhang, J., Davidson, C., Walkley, S.U., Bagel, J.H., Vite, C., Yanjanin, N.M., Porter, F.D., Schaffer, J.E., and Ory, D.S. (2013) Identification of NiemannPick C1 disease biomarkers through sphingolipid profiling. Journal of Lipid Research 54: 2800-2814.

German, D.C., Liang, C.L., Song, T., Yazdani, U., Xie, C., and Dietschy, J.M. (2002) Neurodegeneration in the Niemann-Pick C mouse: glial involvement. Neuroscience 109: 437-450. 
bioRxiv preprint doi: https://doi.org/10.1101/2020.11.06.369447; this version posted November 7, 2020. The copyright holder for this preprint (which was not certified by peer review) is the author/funder, who has granted bioRxiv a license to display the preprint in perpetuity. It is made available under aCC-BY 4.0 International license.

German, D.C., Quintero, E.M., Liang, C.L., Ng, B., Punia, S., Xie, C., and Dietschy, J.M. (2001) Selective neurodegeneration, without neurofibrillary tangles, in a mouse model of Niemann-Pick $C$ disease. J Comp Neurol 433: 415-425.

Gilbert, E.F., Callahan, J., Viseskul, C., and Opitz, J.M. (1981) Niemann-Pick disease type C. Pathological, histochemical, ultrastructural and biochemical studies. Eur J Pediatr 136: 263274.

Goffinet, A., and Rakic, P., (2000) Mouse Brain Development. Springer Berlin Heidelberg : Imprint : Springer, Berlin, Heidelberg.

Goodlett, C.R., and Mittleman, G., (2017) Chapter 9 - The Cerebellum. In: Conn's Translational Neuroscience. P.M. Conn (ed). San Diego: Academic Press, pp. 191-212.

Griffiths, W.J., Abdel-Khalik, J., Crick, P.J., Yutuc, E., and Wang, Y. (2016) New methods for analysis of oxysterols and related compounds by LC-MS. The Journal of Steroid Biochemistry and Molecular Biology 162: 4-26.

Griffiths, W.J., Crick, P.J., Wang, Y., Ogundare, M., Tuschl, K., Morris, A.A., Bigger, B.W., Clayton, P.T., and Wang, Y. (2013) Analytical strategies for characterization of oxysterol lipidomes: Liver X receptor ligands in plasma. Free Radical Biology and Medicine 59: 69-84.

Griffiths, W.J., and Wang, Y. (2019) Oxysterol research: a brief review. Biochem Soc Trans 47: 517526.

Hankin, J.A., Farias, S.E., Barkley, R.M., Heidenreich, K., Frey, L.C., Hamazaki, K., Kim, H.Y., and Murphy, R.C. (2011) MALDI mass spectrometric imaging of lipids in rat brain injury models. J Am Soc Mass Spectrom 22: 1014-1021.

Harayama, T., and Riezman, H. (2018) Understanding the diversity of membrane lipid composition. Nature Reviews Molecular Cell Biology 19: 281-296.

Hawes, C.M., Wiemer, H., Krueger, S.R., and Karten, B. (2010) Pre-synaptic defects of NPC1-deficient hippocampal neurons are not directly related to plasma membrane cholesterol. $J$ Neurochem 114: 311-322.

Hedrich, H.J., and Bullock, G.R., (2012) The laboratory mouse. Elsevier Academic Press, Amsterdam.

Heverin, M., Bogdanovic, N., Lutjohann, D., Bayer, T., Pikuleva, I., Bretillon, L., Diczfalusy, U., Winblad, B., and Bjorkhem, I. (2004) Changes in the levels of cerebral and extracerebral sterols in the brain of patients with Alzheimer's disease. J Lipid Res 45: 186-193.

Higashi, Y., Murayama, S., Pentchev, P.G., and Suzuki, K. (1993) Cerebellar degeneration in the Niemann-Pick type C mouse. Acta Neuropathol 85: 175-184.

Kanungo, S., Soares, N., He, M., and Steiner, R.D. (2013) Sterol metabolism disorders and neurodevelopment-an update. Developmental Disabilities Research Reviews 17: 197-210.

Kluver, H., and Barrera, E. (1953) A method for the combined staining of cells and fibers in the nervous system. J Neuropathol Exp Neurol 12: 400-403.

Kulinski, A., and Vance, J.E. (2007) Lipid Homeostasis and Lipoprotein Secretion in Niemann-Pick C1deficient Hepatocytes. Journal of Biological Chemistry 282: 1627-1637.

Lajtha, A., Tettamanti, G., and Goracci, G. (2010) Handbook of Neurochemistry and Molecular Neurobiology : Neural Lipids.

Larsson, S.C., and Markus, H.S. (2018) Does Treating Vascular Risk Factors Prevent Dementia and Alzheimer's Disease? A Systematic Review and Meta-Analysis. Journal of Alzheimer's disease : JAD 64: 657-668.

Lein, E.S., Hawrylycz, M.J., Ao, N., Ayres, M., Bensinger, A., Bernard, A., Boe, A.F., Boguski, M.S., Brockway, K.S., Byrnes, E.J., Chen, L., Chen, L., Chen, T.-M., Chi Chin, M., Chong, J., Crook, B.E., Czaplinska, A., Dang, C.N., Datta, S., Dee, N.R., Desaki, A.L., Desta, T., Diep, E., Dolbeare, T.A., Donelan, M.J., Dong, H.-W., Dougherty, J.G., Duncan, B.J., Ebbert, A.J., Eichele, G., Estin, L.K., Faber, C., Facer, B.A., Fields, R., Fischer, S.R., Fliss, T.P., Frensley, C., Gates, S.N., Glattfelder, K.J., Halverson, K.R., Hart, M.R., Hohmann, J.G., Howell, M.P., Jeung, D.P., Johnson, R.A., Karr, P.T., Kawal, R., Kidney, J.M., Knapik, R.H., Kuan, C.L., Lake, J.H., Laramee, A.R., Larsen, K.D., Lau, C., Lemon, T.A., Liang, A.J., Liu, Y., Luong, L.T., Michaels, J., Morgan, 
bioRxiv preprint doi: https://doi.org/10.1101/2020.11.06.369447; this version posted November 7, 2020. The copyright holder for this preprint (which was not certified by peer review) is the author/funder, who has granted bioRxiv a license to display the preprint in perpetuity. It is made available under aCC-BY 4.0 International license.

J.J., Morgan, R.J., Mortrud, M.T., Mosqueda, N.F., Ng, L.L., Ng, R., Orta, G.J., Overly, C.C., Pak, T.H., Parry, S.E., Pathak, S.D., Pearson, O.C., Puchalski, R.B., Riley, Z.L., Rockett, H.R., Rowland, S.A., Royall, J.J., Ruiz, M.J., Sarno, N.R., Schaffnit, K., Shapovalova, N.V., Sivisay, T., Slaughterbeck, C.R., Smith, S.C., Smith, K.A., Smith, B.I., Sodt, A.J., Stewart, N.N., Stumpf, K.R., Sunkin, S.M., Sutram, M., Tam, A., Teemer, C.D., Thaller, C., Thompson, C.L., Varnam, L.R., Visel, A., Whitlock, R.M., Wohnoutka, P.E., Wolkey, C.K., Wong, V.Y., et al. (2007) Genomewide atlas of gene expression in the adult mouse brain. Nature 445: 168-176.

Liu, B., Turley, S.D., Burns, D.K., Miller, A.M., Repa, J.J., and Dietschy, J.M. (2009) Reversal of defective lysosomal transport in NPC disease ameliorates liver dysfunction and neurodegeneration in the npc1-/- mouse. Proceedings of the National Academy of Sciences 106: 2377.

Liu, Y., Wu, Y.-P., Wada, R., Neufeld, E.B., Mullin, K.A., Howard, A.C., Pentchev, P.G., Vanier, M.T., Suzuki, K., and Proia, R.L. (2000) Alleviation of neuronal ganglioside storage does not improve the clinical course of the Niemann-Pick C disease mouse. Human Molecular Genetics 9: 1087-1092.

Loftus, S.K., Morris, J.A., Carstea, E.D., Gu, J.Z., Cummings, C., Brown, A., Ellison, J., Ohno, K., Rosenfeld, M.A., Tagle, D.A., Pentchev, P.G., and Pavan, W.J. (1997) Murine Model of Niemann-Pick C Disease: Mutation in a Cholesterol Homeostasis Gene. Science 277: 232.

Mast, N., Anderson, K.W., Lin, J.B., Li, Y., Turko, I.V., Tatsuoka, C., Bjorkhem, I., and Pikuleva, I.A. (2017) Cytochrome P450 27A1 Deficiency and Regional Differences in Brain Sterol Metabolism Cause Preferential Cholestanol Accumulation in the Cerebellum. J Biol Chem 292: $4913-4924$.

Maxfield, F.R., and van Meer, G. (2010) Cholesterol, the central lipid of mammalian cells. Curr Opin Cell Biol 22: 422-429.

McDonald, J.G., Thompson, B.M., McCrum, E.C., and Russell, D.W., (2007) Extraction and Analysis of Sterols in Biological Matrices by High Performance Liquid Chromatography Electrospray Ionization Mass Spectrometry. In: Lipidomics and Bioactive Lipids: Mass-SpectrometryBased Lipid Analysis. pp. 145-170.

Morris, M.D., Bhuvaneswaran, C., Shio, H., and Fowler, S. (1982) Lysosome lipid storage disorder in NCTR-BALB/c mice. I. Description of the disease and genetics. Am J Pathol 108: 140-149.

Muller, L., Baldwin, K., Barbacci, D.C., Jackson, S.N., Roux, A., Balaban, C.D., Brinson, B.E., McCully, M.I., Lewis, E.K., Schultz, J.A., and Woods, A.S. (2017) Laser Desorption/Ionization Mass Spectrometric Imaging of Endogenous Lipids from Rat Brain Tissue Implanted with Silver Nanoparticles. Journal of The American Society for Mass Spectrometry 28: 1716-1728.

Naureckiene, S., Sleat, D.E., Lackland, H., Fensom, A., Vanier, M.T., Wattiaux, R., Jadot, M., and Lobel, P. (2000) Identification of \&lt;em\&gt;HE1 \&lt;/em\&gt;as the Second Gene of Niemann-Pick C Disease. Science 290: 2298.

Niehaus, M., Soltwisch, J., Belov, M.E., and Dreisewerd, K. (2019) Transmission-mode MALDI-2 mass spectrometry imaging of cells and tissues at subcellular resolution. Nature Methods 16: 925931.

Norris, J.L., and Caprioli, R.M. (2013) Analysis of tissue specimens by matrix-assisted laser desorption/ionization imaging mass spectrometry in biological and clinical research. Chem Rev 113: 2309-2342.

Palmeri, S., Battisti, C., Federico, A., and Guazzi, G.C. (1994) Hypoplasia of the corpus callosum in Niemann-Pick type $C$ disease. Neuroradiology 36: 20-22.

Patti, G.J., Shriver, L.P., Wassif, C.A., Woo, H.K., Uritboonthai, W., Apon, J., Manchester, M., Porter, F.D., and Siuzdak, G. (2010) Nanostructure-initiator mass spectrometry (NIMS) imaging of brain cholesterol metabolites in Smith-Lemli-Opitz syndrome. Neuroscience 170: 858-864.

Picard, C., Julien, C., Frappier, J., Miron, J., Théroux, L., Dea, D., Breitner, J.C.S., and Poirier, J. (2018) Alterations in cholesterol metabolism-related genes in sporadic Alzheimer's disease. Neurobiology of aging 66: 180.e181-180.e189. 
bioRxiv preprint doi: https://doi.org/10.1101/2020.11.06.369447; this version posted November 7, 2020. The copyright holder for this preprint (which was not certified by peer review) is the author/funder, who has granted bioRxiv a license to display the preprint in perpetuity. It is made available under aCC-BY 4.0 International license.

Porter, F.D., and Herman, G.E. (2011) Malformation syndromes caused by disorders of cholesterol synthesis. Journal of lipid research 52: 6-34.

Quan, G., Xie, C., Dietschy, J.M., and Turley, S.D. (2003) Ontogenesis and regulation of cholesterol metabolism in the central nervous system of the mouse. Developmental Brain Research 146: 87-98.

Reid, P.C., Lin, S., Vanier, M.T., Ohno-Iwashita, Y., Harwood, H.J., Hickey, W.F., Chang, C.C.Y., and Chang, T.Y. (2008) Partial blockage of sterol biosynthesis with a squalene synthase inhibitor in early postnatal Niemann-Pick type $\mathrm{C}$ npcnih null mice brains reduces neuronal cholesterol accumulation, abrogates astrogliosis, but may inhibit myelin maturation. Journal of Neuroscience Methods 168: 15-25.

Rompp, A., and Spengler, B. (2013) Mass spectrometry imaging with high resolution in mass and space. Histochem Cell Biol 139: 759-783.

Roux, A., Muller, L., Jackson, S.N., Post, J., Baldwin, K., Hoffer, B., Balaban, C.D., Barbacci, D., Schultz, J.A., Gouty, S., Cox, B.M., and Woods, A.S. (2016) Mass spectrometry imaging of rat brain lipid profile changes over time following traumatic brain injury. Journal of Neuroscience Methods 272: 19-32.

Russell, D.W. (2003) The enzymes, regulation, and genetics of bile acid synthesis. Annu Rev Biochem 72: 137-174.

Saher, G., and Stumpf, S.K. (2015) Cholesterol in myelin biogenesis and hypomyelinating disorders. Biochim Biophys Acta 1851: 1083-1094.

Schneider, C.A., Rasband, W.S., and Eliceiri, K.W. (2012) NIH Image to ImageJ: 25 years of image analysis. Nature Methods 9: 671-675.

Shio, H., Fowler, S., Bhuvaneswaran, C., and Morris, M.D. (1982) Lysosome lipid storage disorder in NCTR-BALB/c mice. II. Morphologic and cytochemical studies. Am J Pathol 108: 150-159.

Simons, K., and Ikonen, E. (2000) How Cells Handle Cholesterol. Science 290: 1721-1726.

Sjövall, P., Lausmaa, J., and Johansson, B. (2004) Mass Spectrometric Imaging of Lipids in Brain Tissue. Analytical Chemistry 76: 4271-4278.

Solheim, S., Hutchinson, S.A., Lundanes, E., Wilson, S.R., Thorne, J.L., and Roberg-Larsen, H. (2019) Fast liquid chromatography-mass spectrometry reveals side chain oxysterol heterogeneity in breast cancer tumour samples. J Steroid Biochem Mol Biol 192: 105309.

Soltwisch, J., Heijs, B., Koch, A., Vens-Cappell, S., Höhndorf, J., and Dreisewerd, K. (2020) MALDI-2 on a Trapped Ion Mobility Quadrupole Time-of-Flight Instrument for Rapid Mass Spectrometry Imaging and Ion Mobility Separation of Complex Lipid Profiles. Anal Chem.

Soltwisch, J., Kettling, H., Vens-Cappell, S., Wiegelmann, M., Müthing, J., and Dreisewerd, K. (2015) Mass spectrometry imaging with laser-induced postionization. Science 348: 211.

Spengler, B. (2015) Mass spectrometry imaging of biomolecular information. Anal Chem 87: 64-82.

Steck, T.L., and Lange, Y. (2018) Transverse distribution of plasma membrane bilayer cholesterol: Picking sides. Traffic 19: 750-760.

Sturrock, R.R. (1980) Myelination of the mouse corpus callosum. Neuropathology and applied neurobiology 6: 415-420.

Tabas, I. (2002) Cholesterol in health and disease. J Clin Invest 110: 583-590.

Tobias, F., Olson, M.T., and Cologna, S.M. (2018) Mass spectrometry imaging of lipids: untargeted consensus spectra reveal spatial distributions in Niemann-Pick disease type C1. J Lipid Res 59: 2446-2455.

Trim, P.J., Atkinson, S.J., Princivalle, A.P., Marshall, P.S., West, A., and Clench, M.R. (2008) Matrixassisted laser desorption/ionisation mass spectrometry imaging of lipids in rat brain tissue with integrated unsupervised and supervised multivariant statistical analysis. Rapid communications in mass spectrometry: RCM 22: 1503-1509.

van Meer, G., Voelker, D.R., and Feigenson, G.W. (2008) Membrane lipids: where they are and how they behave. Nat Rev Mol Cell Biol 9: 112-124. 
Vanier, M.T. (2015) Complex lipid trafficking in Niemann-Pick disease type C. Journal of inherited metabolic disease 38: 187-199.

Wahlsten, D. (1984) Growth of the mouse corpus callosum. Brain Res 317: 59-67.

Woods, A.S., and Jackson, S.N. (2006) Brain tissue lipidomics: direct probing using matrix-assisted laser desorption/ionization mass spectrometry. AAPS J 8: E391-395.

Xu, L., Kliman, M., Forsythe, J.G., Korade, Z., Hmelo, A.B., Porter, N.A., and McLean, J.A. (2015) Profiling and Imaging Ion Mobility-Mass Spectrometry Analysis of Cholesterol and 7Dehydrocholesterol in Cells Via Sputtered Silver MALDI. Journal of The American Society for Mass Spectrometry 26: 924-933.

Yutuc, E., Angelini, R., Baumert, M., Mast, N., Pikuleva, I., Newton, J., Clench, M.R., Skibinski, D.O.F., Howell, O.W., Wang, Y., and Griffiths, W.J. (2020) Localization of sterols and oxysterols in mouse brain reveals distinct spatial cholesterol metabolism. Proceedings of the National Academy of Sciences 117: 5749.

Zhou, S., Davidson, C., McGlynn, R., Stephney, G., Dobrenis, K., Vanier, M.T., and Walkley, S.U. (2011) Endosomal/Lysosomal Processing of Gangliosides Affects Neuronal Cholesterol Sequestration in Niemann-Pick Disease Type C. Am J Pathol 179: 890-902. 
\begin{tabular}{l|ll} 
Figure 2 & $A$ & NL: $1.20 E 3$ ITMS + c NSI Full ms3 \\
$518.41 @ c i d 35.00$ & $439.40 @ c i d 40.00$
\end{tabular}

B NL: $1.50 E 3$ ITMS + c NSI Full ms3

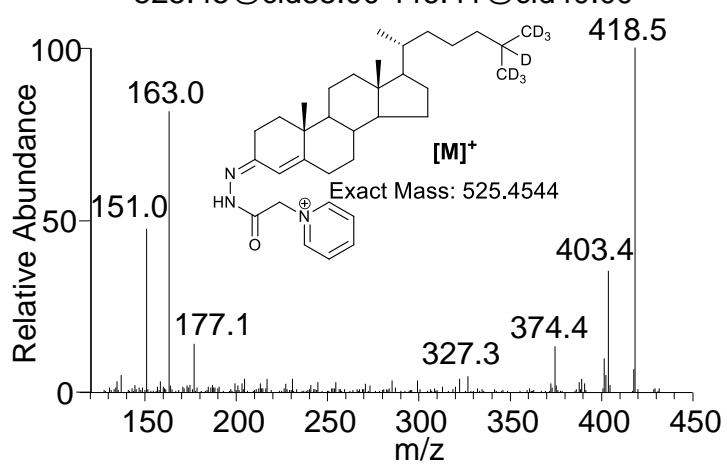

C NL: $1.24 E 5$ ITMS + c ESI Full ms3

D NL: 4.17E4 ITMS + c ESI Full ms3 518.41@cid30.00439.37@cid35.00

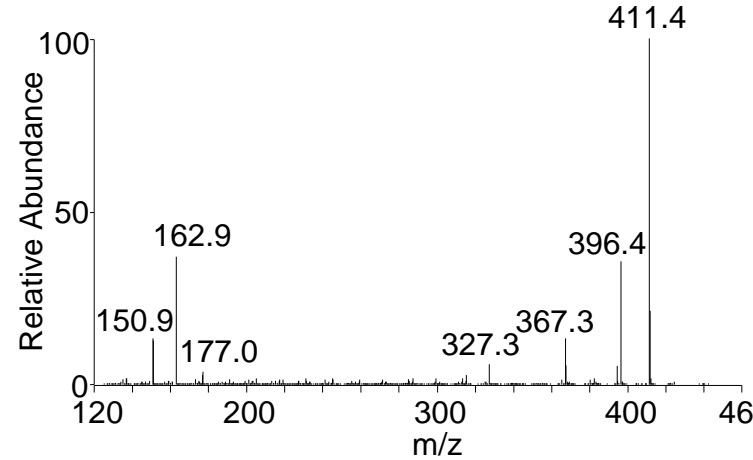

E $\quad M^{3}(518.4) \rightarrow 439.4 \rightarrow 163.1 \pm 0.3$
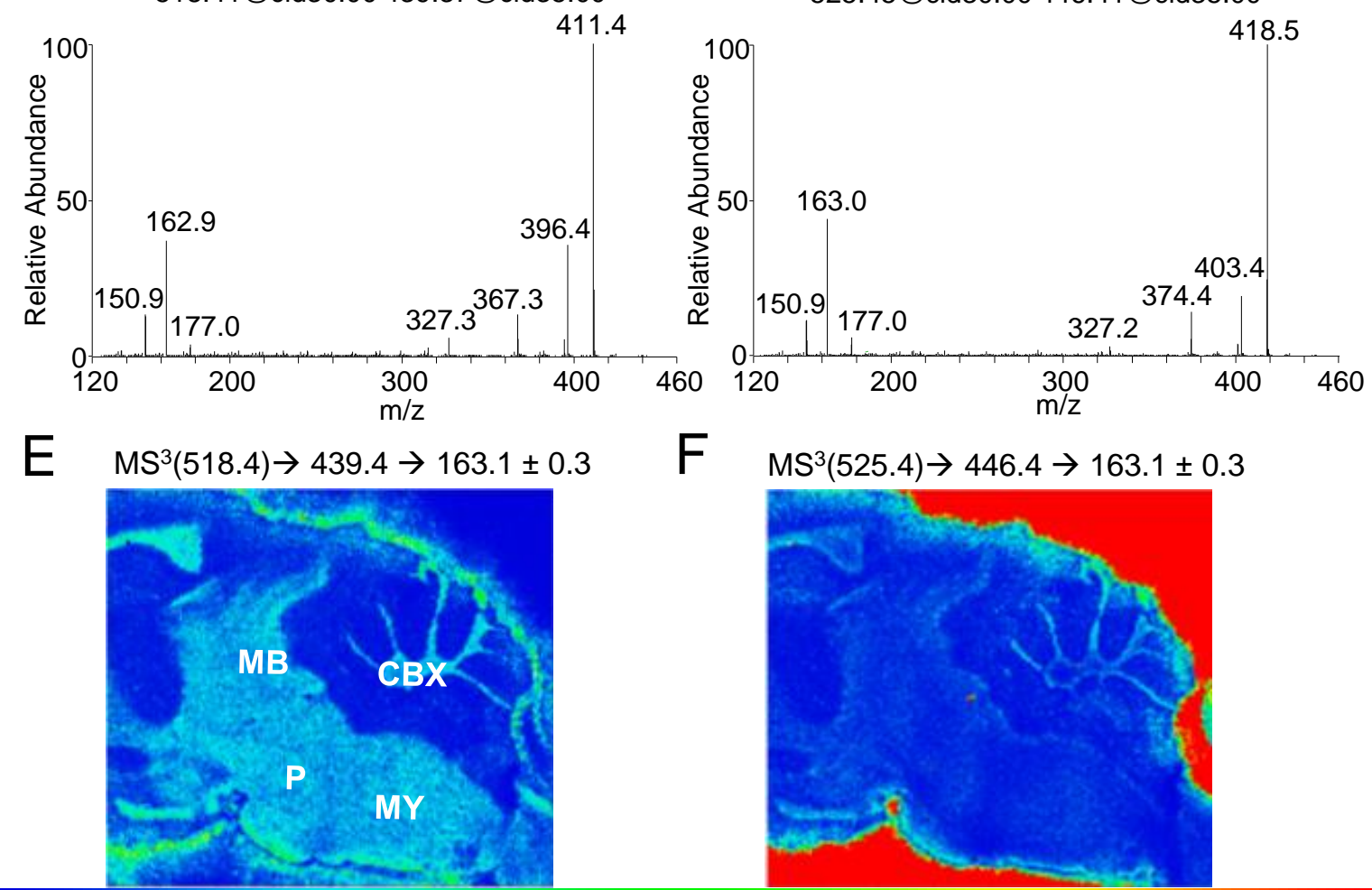

F $\quad \mathrm{MS}^{3}(525.4) \rightarrow 446.4 \rightarrow 163.1 \pm 0.3$

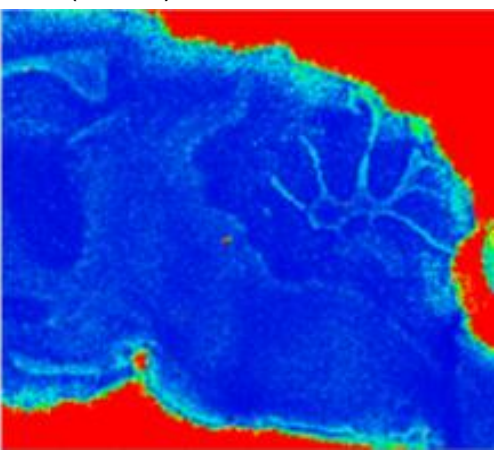



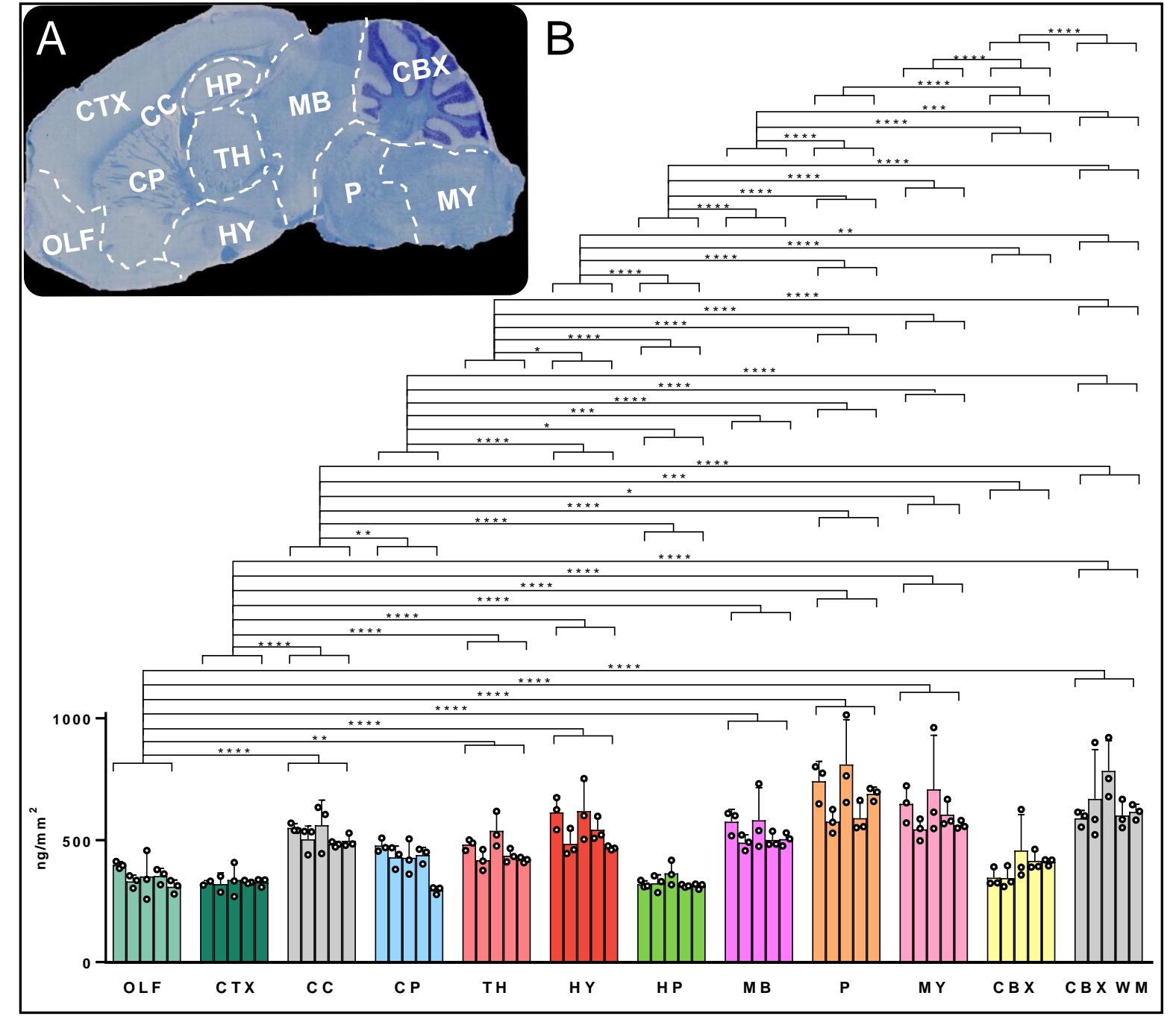



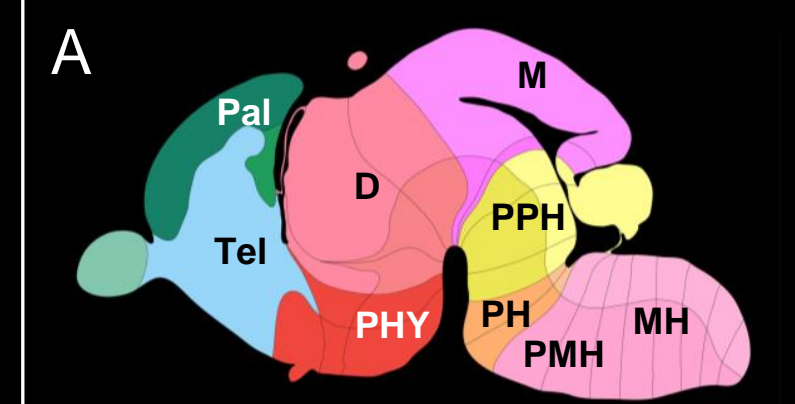

C

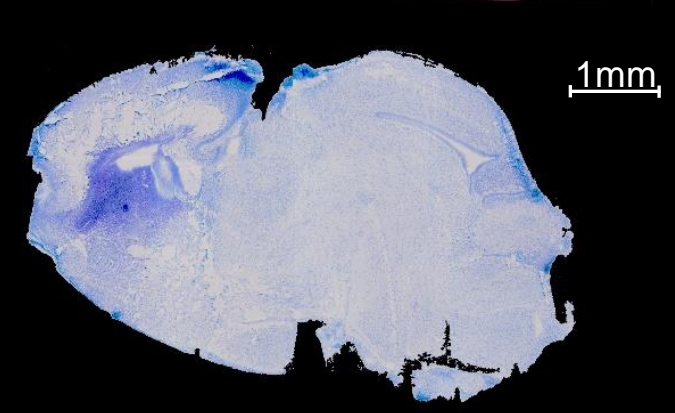

E

$\mathrm{m} / \mathrm{z} 518.41 \pm 0.25$

$m / z 518.42 \pm 0.25$

D
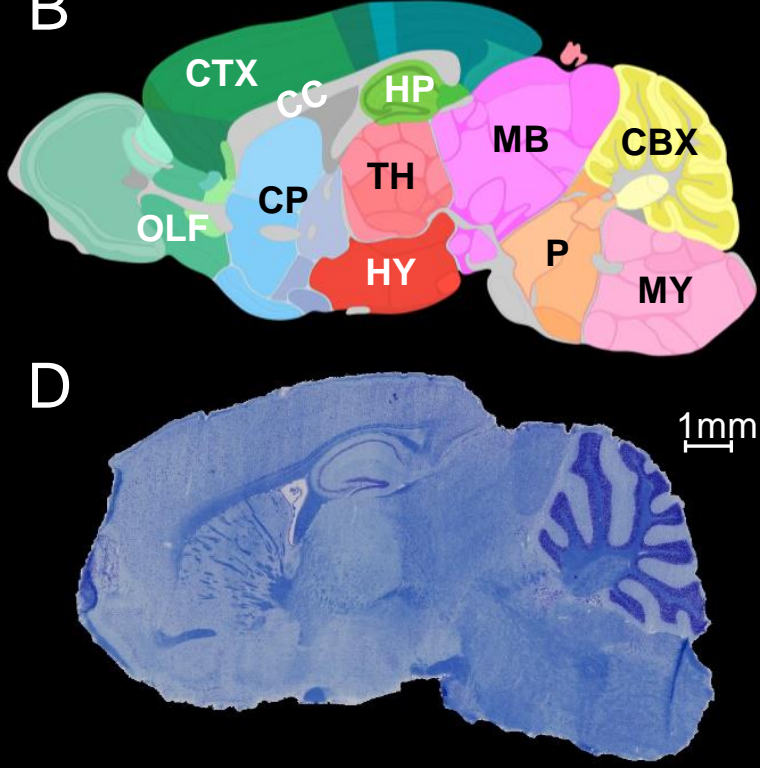

F

$1 \mathrm{~mm}$
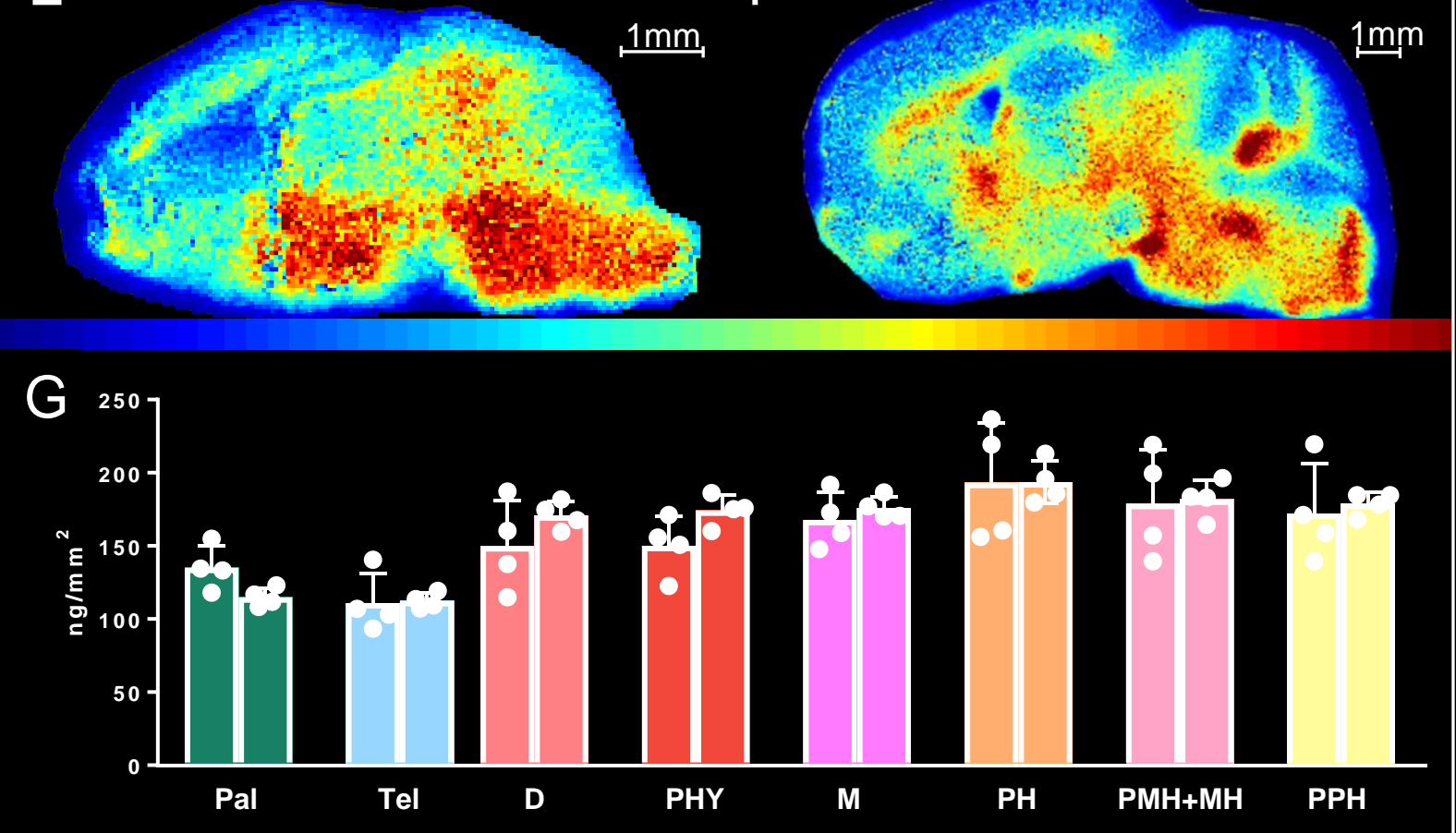


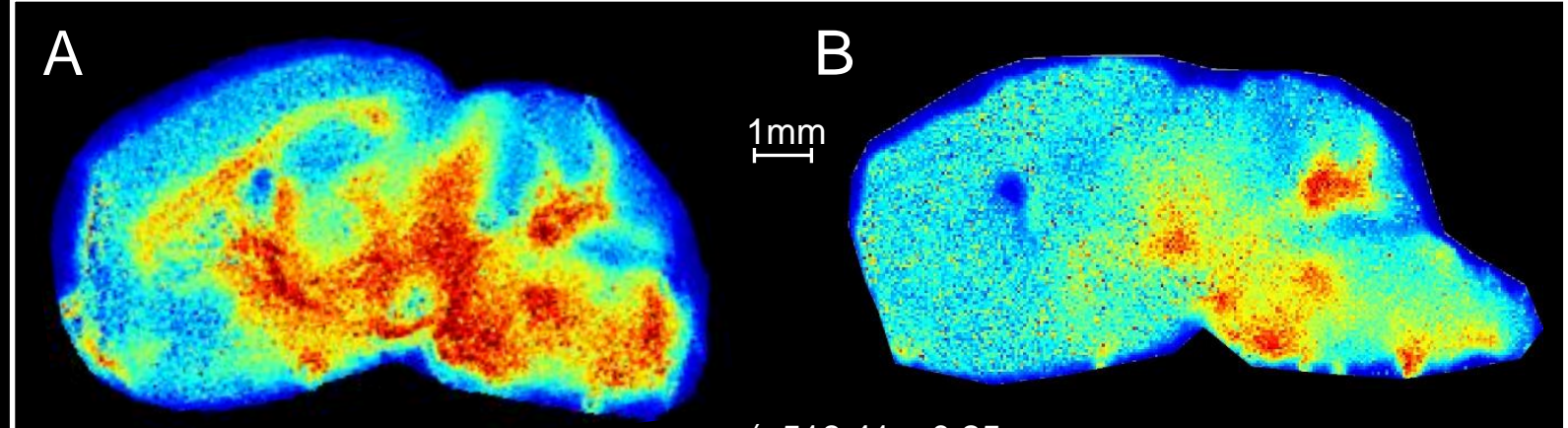

$m / z 518.41 \pm 0.25$

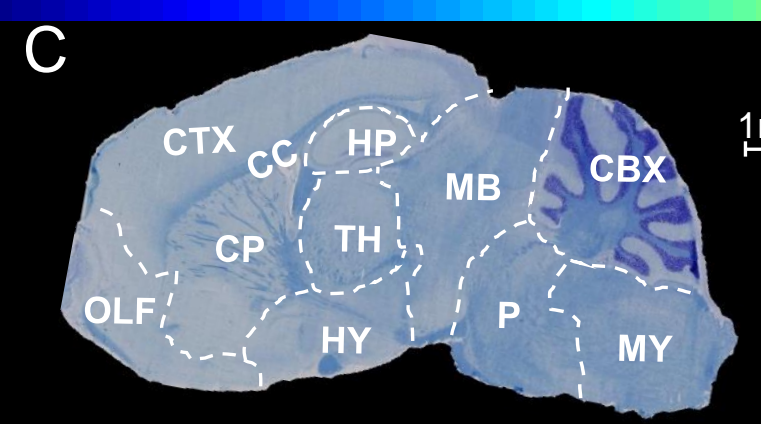

E

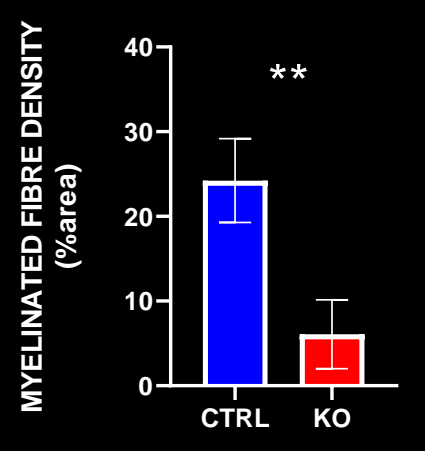

D

CTX ${ }_{\mathrm{C}} \mathrm{CH}$

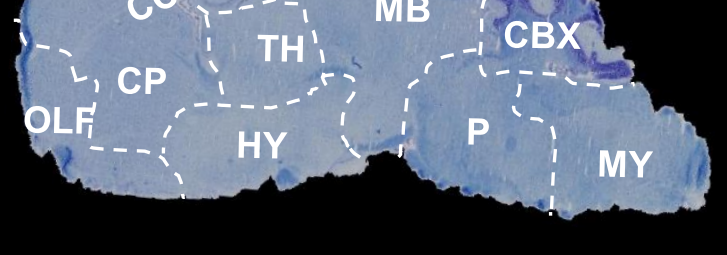

F

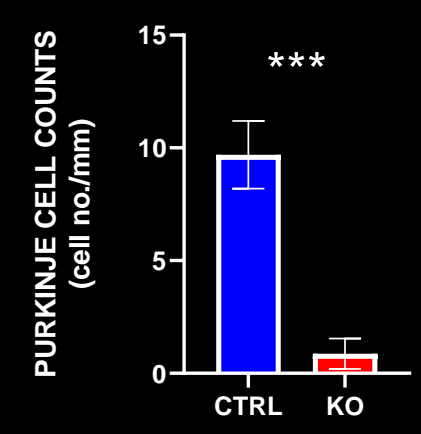

G

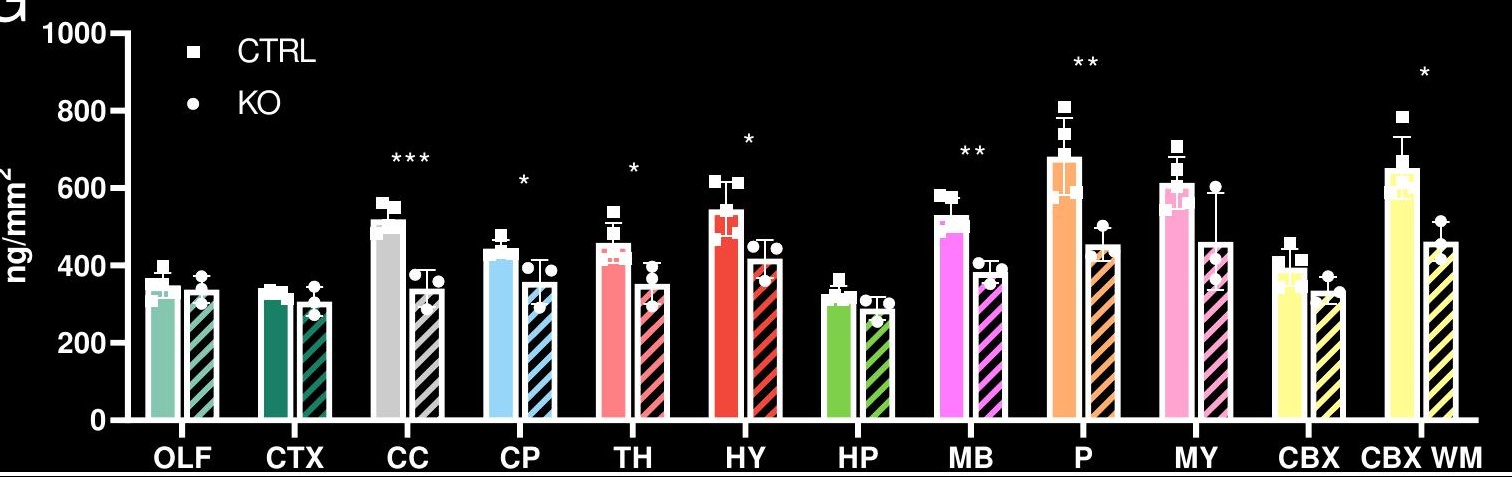

